\title{
Palaeohydrological changes during the mid and late Holocene in the Carpathian
} \section{area, central-eastern Europe}

(1)

(1)

Aritina Haliuc ${ }^{1,2}$, Daniel Veres ${ }^{2}$, Achim Brauer $^{3}$, Katalin Hubay $^{4}$, Simon M. Hutchinson ${ }^{5}$, Robert Begy ${ }^{2,6}$, Mihaly Braun $^{3}$

${ }^{1}$ Stefan cel Mare University of Suceava, Department of Geography, Suceava, Romania

${ }^{2}$ Institute of Speleology, Romanian Academy, Cluj-Napoca, Romania

${ }^{3}$ GFZ German Research Centre for Geosciences, Section 5.2 Climate Dynamics and Landscape Evolution, Potsdam,

Germany

${ }^{4}$ Hertelendi Laboratory of Environmental Studies, Atomki, Debrecen, Hungary

${ }^{5}$ School of Environment and Life Sciences, Peel Building, University of Salford, Salford, UK

${ }^{6}$ Faculty of Environmental Science, Babes-Bolyai University, Cluj-Napoca, Romania

Correspondence to:

Aritina Haliuc, Stefan cel Mare University of Suceava, Department of Geography, 13 Universitatii str, 720229 Suceava,

Romania; Email: aritinahaliuc@gmail.com

Daniel Veres, Romanian Academy, Institute of Speleology, 5 Clinicilor str, 400006 Cluj-Napoca, Romania; Email: daniel.veres@ubbcluj.ro

KEYWORDS:

lacustrine sediments; geochemistry; environmental magnetism; microfacies; palaeohydrological gradients; Carpathians

\begin{abstract}
Multi-proxy, high-resolution analyses (lithological, geochemical, environmental magnetism) anchored by $22{ }^{14} \mathrm{C}$ dates, of a $5.53 \mathrm{~m}$ long sediment core from Lake Ighiel (Romanian Carpathians, central-eastern Europe) allowed the reconstruction of key local, catchment-lacustrine dynamics and an appraisal of palaeohydrological and palaeoclimatic gradients acting regionally over the last 6000 years. The first sedimentological phase of the record from 6030 to $4200 \mathrm{cal} \mathrm{yr} \mathrm{BP}$, is
\end{abstract}


characterised by low productivity and high detrital input indicating surface runoff processes due to enhanced rainfall. This interpretation is in agreement with other hydrological reconstructions reporting increased precipitation also in CE Europe, NE Mediterranean, and also inferred summer and winter latitudinal temperature gradients (LTG) (as defined by Davis and Bewer, 2009), showing a strong connectivity between basin-lacustrine dynamics and the establishment of the dominant, Atlantic atmospheric circulation pattern in the area. The lacustrine system was more stable between 4200 and 2500 cal yr BP when clastic inputs diminished and biological productivity increased. During this interval, the coherence of Lake Ighiel's multi-century detrital events, identified in a range of proxy-data (albeit different in frequency and magnitude), with flood activity in central Europe (the Alps) suggests a common moisture forcing (Atlantic and periodically Mediterranean influences). In contrast, different reconstructions from the NE Mediterranean indicate a distinct NW-SE hydro-climatic gradient. A more complex and variable trend is depicted in Lake Ighiel sedimentation during the last $\sim 2500$ years showing a variable detrital trend likely reflecting an intriguing hydrological pattern which is in agreement with intervals of increased aridity phases during a generally moister period. Comparing our sedimentological results with published pollen records from the nearby area clearly show anthropogenic imprints during the Dacian-Roman Period and especially the Middle Ages towards present times. The $\sim 6000$-year long sedimentary record of Lake Ighiel contributes to understanding of mid and late Holocene palaeohydrological changes in the Carpathians and highlights the importance of latitudinal gradients in driving hydrological variability in continental Europe-

\section{Introduction}

Sediment geochemistry, environmental magnetism and various sedimentological properties offer compelling information on the factors and processes acting within a lake basin and its watershed, including the strength of sediment fluxes, the rate of atmospheric deposition and in-lake depositional processes that ultimately control sediment accumulation patterns and biogeochemical characteristics (Koinig et al., 2003; Tribovillard et al., 2006; Kylander et al., 2011; Braun et al., 2013; Czymzik et al., 2013; Swierczynski et al., 2013; Wirth et al., 2013; Magny et al., 2014). Most of the material deposited in small lacustrine basins derives from the adjacent catchment via in-wash (fluvial inputs, slope runoff) and usually preserves a specific signature related to the regional geology, including soil and vegetation cover (Cohen, 2003). Insolation and rainfall rate variability (Martin-Puertas et al., 2011) commonly triggered environmental change during the Holocene. Variations in different forcing factors are expected to be reflected by changes in sediment flux, lake levels oscillation as well as 
western and southern Europe with a long tradition in palaeoenvironmental reconstructions using lacustrine sediments, the central-eastern regions of Europe are less well studied mainly due to the penury of well-dated lacustrine records (Magyari et al., 2014; Feurdean et al., 2014). However, significant progress in peat-based palaeoenvironmental studies has allowed the reconstruction of past vegetation characteristics (Cristea et al., 2013; Feurdean et al., 2016; Gałka et al., 2016; Tanţău et al., 2014). Despite the link between watershed vegetation/soil cover and lacustrine dynamics (Magyari et al., 2009), relatively few studies have undertaken reconstructions including sedimentological (Braun et al., 2013; Magyari et al., 2009; 2013; 2014) and/or quantitative proxies (Feurdean et al., 2008a; Schnitchen et al., 2006).

Present-day temperature and humidity gradients across Romania are enforced by the Carpathian mountain belt which

mediates the regional impact of Atlantic, Mediterranean and Siberian air masses through air temperature and moisture changes (Busuioc et al., 2015). It has been suggested that the winter climate anomalies in Romania are mainly influenced by Atlantic Oscillation (AO) teleconnections (regionally expressed as North Atlantic Oscillation - NAO) (Bojariu and Giorgi, 2005; Bojariu and Paliu, 2001; Hurrell et al., 2003); known as an important mode of large-scale atmospheric variability over Northern Hemisphere (Hurrell et al., 2003). For example, winter positive thermal and negative precipitation anomalies have been associated with a positive winter NAO index (Bojariu and Paliu, 2001). Summer and autumn thermal anomalies seem to be connected to decadal-scale variability known as Atlantic Meridional Oscillation (AMO) (Ionita et al., 2013). Therefore, CE Europe and especially the Carpathian region are considered sensitive to hydrological forcing (Drăguşin et al., 2014; Finsinger et al., 2014; Gałka et al., 2016). Providing additional palaeoenvironmental data from this region will lead to better constraining the spatial and temporal variability in hydroclimatic gradients between west-east and north-south Europe at the Holocene scale (Davis and Brewer, 2009; Davis et al., 2003; Magny et al., 2013; McDermott et al., 2011; Roberts et al., 2012; Drăguşin et al., 2014).

In addition to climate forcing, lake environments are increasingly influenced by human activities (Schumacher et al., 2016). In particular, the Carpathian Mountains have provided essential natural resources for diverse economical and technological activities and used as Eurasian migration routes since prehistoric times. Archaeological and palaeobotanical evidence document farming and mining activities in the Carpathians since the Neolithic and increasingly from the Bronze Age until the present day (Giosan et al., 2012; Schumacher et al., 2016).

Here we present first results from multi-proxy palaeolimnological research on the sediment record of Lake Ighiel (western Romania) covering the last 6000 years with the aim to reconstruct the lake-catchment system history and to assess the sensitivity of this record to past regional and extra-regional hydrological changes. The interpretation of the sedimentary 
record in terms of palaeoclimate and/or local catchment dynamics is compared with palaeohydrological records from the Alps (Czymzik et al., 2013; Swierczynski et al., 2013; Wirth et al., 2013) and the Balkan Peninsula (Lacey et al., 2014; Morellon et al., 2016; Wagner et al., 2010; Zhang et al., 2014). This comparison thereby places the Lake Ighiel record in an ideal, middle range position to assessing the postulated west-east and north-south gradients of European hydrological regimes during the study period.

\section{Regional setting}

Lake Ighiel (46 $\left.10^{\prime} 50^{\prime \prime} \mathrm{N}, 23^{\circ} 22^{\prime} 00^{\prime \prime} \mathrm{E}\right)$ (Fig.1) is located on the eastern side of the Trascau Massif (part of the Apuseni Mountains), at an altitude of $924 \mathrm{~m}$ a.s.l., and is currently protected as part of the Iezerul Ighiel Natural Reserve. It is assumed that the lake was formed following the collapse of a karst feature damming the Iezer brook (Pop and Mahara, 1965). However, its morpho-bathymetric profile (Pop and Mahara, 1965) is typical of a steep-sided, flat-bottomed karst doline suggesting that it most likely represents a natural karst lake. The lake has a catchment area of 381 ha, a water surface of 3.20 ha and a water volume of $225.000 \mathrm{~m}^{3}$. At present the lake receives direct inputs (albeit highly intermittent) from small tributaries (Fig.1) although the main water sources are rainfall, slope-runoff and groundwater; its location within a karst environment makes it very sensitive to seasonal water supply changes. At the time of coring, the maximum depth of the lake reached 8-9 m, albeit high-stands up to $+3 \mathrm{~m}$ are visible as recent erosional features along the rocky shore.

The region is characterised by moderate temperate continental climate with a mean annual temperature between $5^{\circ} \mathrm{C}$ and $7.5^{\circ} \mathrm{C}$ and a mean annual precipitation of $800-1000 \mathrm{~mm}$ (Fig.2). Atmospheric circulation is dominated by westerlies, with a slight Foehn effect over the area that results in mild winters with limited ice cover. The mildness of winters could also reflect the impact of sub-Mediterranean climate influences that extend over south-western Romania (Bojariu and Paliu, 2001).

The vegetation cover of the area comprises mainly deciduous forests with beech (Fagus sylvatica) and hornbeam (Carpinus betulus) as the dominant species. Alder (Alnus glutinosa) trees form a belt adjacent to the lake and grasslands are also found nearby, along the tributary valleys and on the high plateau of Ciumerna (Fig.1). Human impact has presumably been relatively high in the area (mainly by pasturing) and accentuated in the last centuries through road construction, damming of the inflows, extensive forestry and, more recently, recreational activities. However, recent investigations of lake water chemistry (Mihăiescu et al., 2012) and trophic status (Momeu et al., 2015) suggest that the lake environment is still oligotrophic (total phosphorus $<10 \mu \mathrm{m} / 1$ coupled with generally low ammonium, nitrate and total nitrogen values). The dissolved oxygen (DO) values measured throughout the uppermost water column, on a seasonal basis indicate that the water 
column is well mixed (Mihăiescu et al., 2012), with a slight decrease in DO during summer when higher water temperatures result in enhanced biological productivity (Momeu et al., 2015). $\mathrm{pH}$ is slightly alkaline with average values around 8.04 and

114 little seasonal variations, which may be interpreted as possibly reflecting the constant input of carbonate ions from the

115 limestone bedrock. The lake is hosted within Jurassic limestone; however, the southern brook drains an area of Mezozoic mollase and diabaze volcanic rocks. Soil cover changes and extensive erosional features are seen along the main channels, 117 clearly as a result of recent human activities.

\section{Material and methods}

The Lake Ighiel sediment record was retrieved in 2013 using a modified piston corer operated from a floating platform; two sediment cores (IGH-1 and IGH-2, 5 m long each) were extruded from the deepest part of the basin (Fig.3). In order to document the recent spatial variability of sediment accumulation within the basin, the sediment-water interface was sampled in several locations using a modified gravity corer. The cores were labelled, wrapped and transported to laboratory for further analyses where all extruded cores were split in half, cleaned, stratigraphically described and imaged. Gravity core SC-4 (of the five extruded) together with profile IGH-1 was used to establish a composite sedimentary profile of $553 \mathrm{~cm}$ long. The individual piston cores were correlated on the basis of macroscopic inspection following distinct marker layers alongside common features in the sediment magnetic susceptibility properties.

The chronological framework of the composite profile relies on 22 radiocarbon dates performed at the Hertelendi containing wood and twigs followed the protocol for cellulose (BABAB) (Nemec et al., 2010). The graphite targets were obtained were converted into calendar ages reported as years before present (cal yr BP, BP refers to AD 1950) using the INTCAL 13 dataset of Reimer et al. (2013). A list of material subjected to ${ }^{14} \mathrm{C}$ dating and the resulting ages is presented in

Table 1.

The relative chemical composition of sediments was determined using $\mu$-XRF element scanning Itrax Corescanner (Itrax 
to freshly split cores. Core scanning was carried out at $1 \mathrm{~mm}$ resolution and the running settings include a $15 \mathrm{~s}$ exposure time,

$14140 \mathrm{kV}$ tube voltage and a $40 \mathrm{~mA}$ tube current. The detected chemical elements are expressed as counts per rate. Analytical $\mu$ -

142 XRF element studies applied to highly clastic sediments similar to the IGH-1 record have confirmed that the method provides

143 semi-quantitative estimates of element concentration (Croudace et al., 2006; Kylander et al., 2011).

144 Detailed sedimentological information on the nature of clastic and organic materials deposited within the basin was 145 obtained through optical examination of thin sections from selected intervals with marked sedimentological changes, such as

146 laminations. The thin-sections were prepared on 10-cm long segments of fresh sediment, shock-frozen in liquid nitrogen, 147 freeze-dried for $48 \mathrm{~h}$ and impregnated with synthetic resin (Araldite) under vacuum (Brauer and Casanova, 2001). The thin148 sections were examined using a petrographic microscope (Carl Zeiss Axioplan) with different magnifications (from 25x to 149 400x) and light conditions (plain parallel light/partly and fully polarized light). High-quality photographic images were 150 acquired with a Carl Zeiss Axiocam digital camera.

151 The sediment loss-on-ignition parameters including the organic matter (OM), inorganic carbon (IC) and minerogenic 152 matter (MM) were estimated using the widely employed loss-on-ignition technique (Santisteban et al., 2004; Veres, 2002) 153 following sequential heating (at $550^{\circ}$ and $950^{\circ} \mathrm{C}$ for $4 \mathrm{~h}$ ) of $1-\mathrm{cm}^{3}$ samples taken contiguously at 1 -cm resolution along the 154 profile. All loss-on-ignition parameters are expressed as percent (\%) of the sediment dry weight. Relative wet density (WD) 155 has also been calculated with respect to the sediment-wet weight.

156 Volume specific magnetic susceptibility (MS, $\chi$ ) was measured using a Bartington MS2E sensor adapted to measure long sediment cores with 1-mm reading step size. These data helped correlate the sedimentary profiles and offered high-resolution information about sedimentological changes. More detailed environmental magnetic analyses were undertaken on $1-\mathrm{cm}^{3}$ samples collected at every third centimetre from the composite sediment profile and analysed using a MS B sensor. The resulting mass specific dual-frequency dependent susceptibility $\left(\chi_{\mathrm{FD}}\right)$ estimates the concentration of superparamagnetic (SP) 161 minerals in a sample expressed as the difference between low- $\left(\chi_{\mathrm{lf}}\right)$ and high-frequency dependent susceptibility ( $\left.\chi_{\mathrm{hf}}\right)$ (Dearing, 1999).

A Molspin AF Demagnetiser was used to determine Anhysteretic Remanence Magnetisation (ARM) employing facilities at University of Salford, UK. The Saturated Isothermal Remanent Magnetisation (SIRM) (magnetic field $1.0 \mathrm{mT}$ ) and Isothermal Remanent Magnetisation (IRM) backfields were induced with a Molspin Ltd Pulse Magnetiser. IRM backfields were acquired after SIRM measurements by inverting the sample and applying four field pulses of $-20,-40,-100,-300 \mathrm{mT}$, respectively. A Minispin Fluxgate Magnetometer was used after each measurement to determine the resultant magnetic 
remanence (Hutchinson, 1995; Akinyemi et al., 2013). The ARM/SIRM is employed here as a grain-size mineral magnetic indicator (Thompson and Oldfield, 1986), whereas S-ratio, as a qualitative proxy for quantifying the relative concentration of ferrimagnetic (magnetite) versus antiferromagnetic (hematite and goethite) minerals (Fig.6).

A correlation matrix was calculated using the geochemical data set to examine the relationship between pairs of elements and select those elements that hold the stronger associations to be included in further numerical analyses. Therefore, the elements that had correlation indices between 0.4 and 1 and showed a consistent number of associations were included in further statistical analysis and data interpretation. For selected elements (such as $\mathrm{Ti}, \mathrm{Si}, \mathrm{Al}, \mathrm{K}, \mathrm{Ca}, \mathrm{Fe}, \mathrm{Mn}, \mathrm{Rb}, \mathrm{Zr}$ ) we also calculated the coefficient of variance in order to examine the variability characteristic for each lithological unit. The coefficient of variance was calculated by dividing the standard deviation of each geochemical element by its mean (Kylander et al., 2011). Selected chemical elements, the environmental magnetic parameters, as well as the organic and carbonate content were further subjected to principal component analysis (PCA). The PCA was performed using the PAST software version 3 in correlation mode (Hammer et al., 2001).

\section{Results}

\subsection{Age-depth model}

The age-depth model for the Ighiel sediment record has been established by the Bayesian age modelling software Bacon (Blaauw and Christen, 2013) and OxCal (Bronk Ramsey, 2008). Details on the 22-radiocarbon ages included in the construction of the age-depth models are presented in Table 1. All samples show consistent ages except one wood fragment at $442 \mathrm{~cm}$ depth that revealed a too young age of $682 \pm 62{ }^{14} \mathrm{C}$ years BP and was treated as an outlier by both models. Both the Bacon and OxCal-derived age-models are highly concurrent $\left(\mathrm{R}^{2}=0.99\right)$ for the $\mathrm{c} .6030$ years covered by the IGH-1 record. In the following discussion we present only the Bacon age-depth modelling results and all ages quoted refer to calendar years (Fig. 4). The sediment accumulation rate obtained for lithological units I to III ranges between $0.87 \mathrm{~mm} / \mathrm{yr}$ and $0.73 \mathrm{~mm} / \mathrm{yr}$, whereas that obtained for uppermost unit IV gave highest sedimentation rate at $1.26 \mathrm{~mm} / \mathrm{yr}$ (Fig. 4).

\subsection{Lithostratigraphy, geochemistry and magnetic properties}

The composite profile (553 cm long) was divided into four lithological units (Table 2) based on macro- and microscopic description (composition, structure and colour), layer thickness, frequency and behaviour of selected geochemical elements (Fig. 5, 6). 
Lithological unit I (553 - $403 \mathrm{~cm}$, c. 6030 - 4200 cal yr BP) is composed of homogenous grey-brown sandy clay, interrupted by grey clay layers mixed with small gravels (Fig. 5). It represents the basal sediments because the stiffness of this clayey sediment obstructed deeper coring. In the lower part of the unit, spanning $553-500 \mathrm{~cm}$ (6030 to $5000 \mathrm{cal}$ yr BP), the detrital elements (Ti, K, Si and $\mathrm{Zr} / \mathrm{Rb}$ ) register highest values of this interval (Fig. 6). Several short-lived increases in detrital elements are visible around $6000,5700,5000 \mathrm{cal} \mathrm{yr}$ BP. This is accompanied by increasing values for magnetic susceptibility $(\chi) \mathrm{Ca} / \mathrm{Ti}$ shows a contrasting pattern with very low values in the first half of the unit and a considerable increase in the upper part of the interval. The organic matter (OM) and mineral matter (MM) content, as well as Fe/Ti and $\mathrm{Mn} / \mathrm{Fe}$ ratios show only minor fluctuations (Fig. 6). The values of the detrital elements slightly decrease between 500 and $403 \mathrm{~cm}$ depth (5000 - $4200 \mathrm{cal}$ yr BP) whereas $\chi$ exhibits no marked fluctuations. ARM/SIRM registers values below 0.03 $\mu \mathrm{m}$, while S300 parameter has values below $0.75 \mu \mathrm{m}$ with the exception of two peaks around 5500 and 4700 cal yr BP where ARM/SIRM reaches values equal or higher than $0.1 \mu \mathrm{m}$ (Fig. 6).

Lithological unit II (403 - $272 \mathrm{~cm}, 4200$ to $2500 \mathrm{cal}$ yr BP) is composed of grey clay with thin organic (black-brown moss detritus layers) and clayey (light-grey) laminations (Fig. 5) although the lithological change observed is rather transitional. Detrital elements exhibit highly fluctuating values increasing between 4200 and 3300 cal yr BP with less variable trends afterwards. This trend is also mirrored in the magnetic susceptibility values $(\chi)$. Maxima in the detrital 211 elements are registered around 4000, 3600, 3300, and 3100 - 2700 cal yr BP. The organic (OM) and mineral (MM) content 212 also register a two-step trend with oscillating values between 4200 and $3300 \mathrm{cal} \mathrm{yr}$ BP, and increasing values after $3300 \mathrm{cal}$ 213 yr BP (Fig. 6). $\mathrm{Ca} / \mathrm{Ti}$ and also $\mathrm{Fe} / \mathrm{Ti}$ are characterised by highly fluctuating values while $\mathrm{Mn} / \mathrm{Fe}$ ratio follows an increasing 214 trend. At the transition between lithological units I and II, ARM/SIRM and S300 show a steep increase exceeding $0.1 \mu \mathrm{m}$ and $0.75 \mu \mathrm{m}$ respectively. High values are registered over the entire interval with the exception of the strong decrease around 3600 cal yr BP (Fig. 6).

Lithological unit III (272-159 cm; 2500 to $1200 \mathrm{cal}$ yr BP) is composed of brown-red clay with intermittent organic (black-brown) laminations (Fig. 5). When compared with the other lithological units, the organic and clayey laminations are thinner and more frequent, although the composition of lamina is similar. Detrital elements are characterised by a decreasing trend between 2300 and 1700 cal yr BP with a slight increase after $1700 \mathrm{cal}$ yr BP. This trend is mirrored in magnetic susceptibility $(\chi)$ (Fig. 6). Fe/Ti depicts an increasing and highly fluctuating trend while $\mathrm{Ca} / \mathrm{Ti}$ shows rather low but oscillating values (Fig. 6). Organic matter (OM) and mineral (MM) content (although with an oscillating trend) register the 
highest values of the entire profile, which is also reflected in the increasing Mn/Fe ratio. ARM/SIRM and S300 maintain a rather stable trend with values higher than $0.1 \mu \mathrm{m}$ and $0.75 \mu \mathrm{m}$.

Lithological unit IV (159-0 cm, 1200 to -64 cal yr BP) is composed of soft, light-brown clay with thick clayey-sandy and organic detritus layers ( 0.5 to $5 \mathrm{~cm}$ thickness) (Fig. 5). The detrital elements exhibit a decreasing trend with a sharp increase starting from $170 \mathrm{cal}$ yr BP, also mirrored in the magnetic susceptibility $(\chi)$ trend. $\mathrm{Fe} / \mathrm{Ti}$ reflects the same trend while $\mathrm{Ca} / \mathrm{Ti}$ shows contrasting values (Fig. 6). Organic (OM) and mineral matter (MM) content are characterised by oscillating values. ARM/SIRM shows a decreasing trend with values below $0.1 \mu \mathrm{m}$ while S300 values are at the $0.75 \mu \mathrm{m}$ boundary (Fig. 6).

\subsection{Sediment microfacies}

To collect specific information on the composition of sediments deposited in Lake Ighiel during the last 6030 years we employed micro-facies analysis on block samples collected in 30-cm long sections from selected intervals based on the frequency of visually observed laminations and the diverse composition of laminas. Nonetheless, due to the rather similar characteristics observed between the analysed samples, we consider the depositional model proposed as representative for the last 6030 years in the evolution of Lake Ighiel (Fig. 5). The sedimentary matrix is mainly composed of clay, carbonate, organic matter and occasionally intervals rich in diatoms. Carbonates are present as endogenic and detrital minerals. The diagenetic minerals in the record are vivianite and pyrite occurring mainly within lithological unit IV.

Figure 5 illustrates the three main components characteristic for IGH-1 record: i) organic-clay rich event layers composed of clay, amorphous organic material, fresh plant remains (mainly aquatic bryophytes) and carbonate crystals and aggregates with sizes of 2-3 $\mu \mathrm{m}$ and $500 \mu \mathrm{m}$, respectively, more abundant in unit III (159-272 cm, 1200-2500 cal yr BP); ii) clay laminations sometimes capping thin detrital layers, more frequent in units II (272-403 cm, 2500-4200 cal yr BP) and I (403-553 cm, 4200-6030 cal yr BP), and iii) thin layers composed of carbonate crystals and aggregates. Diatoms were not observed in lithological unit I, and the few chrysophyte cysts appear randomly distributed within the clayey matrix. Within lithological unit III (159-272 cm, 1200-2500 cal y BP) the frequency of organic-rich event layers and the thickness of carbonate-rich layer increases and diatoms number start to increase. In lithological unit IV, the organic-rich layers become much rarer, but diatoms become abundant. Thick turbiditic layers only rarely occur in the sediment profile. The most prominent example is the $6 \mathrm{~cm}$ thick layer at $36 \mathrm{~cm}$ sediment depth in unit IV considered an exceptional event restricted to the mouth of the southern brook, probably related to recent human intervention in the Ighiel watershed (Fig.3). 


\subsection{Numerical analyses}

Statistical analyses e.g., principal component, regression and coefficient of variance were used to identify the most relevant set of data and main groups of parameters (geochemical, magnetic) that explain data variability, share a similar behaviour and could be associated with specific sediment sources and depositional processes (Muller et al., 2008).

In order to evaluate the variability observed in the proxies employed, factorial analysis (PCA) was performed on selected elements including geochemical elements (Ti, $\mathrm{Si}, \mathrm{K})$ and ratios $(\mathrm{Mn} / \mathrm{Fe}, \mathrm{K} / \mathrm{Ti}, \mathrm{Zr} / \mathrm{Rb}, \mathrm{Ca} / \mathrm{Ti}, \mathrm{Fe} / \mathrm{Ti}, \mathrm{Pb} / \mathrm{Ti}, \mathrm{Cu} / \mathrm{Ti})$ mineral and organic content (MM, OM) and a suite of magnetic parameters ( $\chi_{\mathrm{lf}}$, ARM, SIRM, ARM/SIRM) (Tabel 3). The first two components, $\mathrm{PC} 1$ and $\mathrm{PC} 2$, explain $58 \%$ of the total variance (Fig. 7). PC1 captures $38 \%$ of the total variance and is mainly represented in a positive direction by $\mathrm{ARM}, \mathrm{SIRM}, \mathrm{Fe} / \mathrm{Ti}, \mathrm{ARM} / \mathrm{SIRM}, \chi_{\mathrm{lf}}$ and on the negative one by $\mathrm{Si}, \mathrm{K}$, mineral matter and Ti (Fig. 7). The highest loadings belong to ARM and SIRM. As magnetic proxies are mainly linked with in-lake processes the positive direction is related to lake internal sediment dynamics (including biological activity) whereas the negative direction represented by $\mathrm{Si}, \mathrm{K}$, and Ti represent a detrital pool associated with sediment fluxes into the basin (Fig. 7).

PC2 explains $20 \%$ of the total variance and is related in a positive direction with $\mathrm{Ti}, \mathrm{Zr} / \mathrm{Rb}$ and $\chi_{\mathrm{lf}}$ and $\mathrm{K} / \mathrm{Ti}, \mathrm{Cu} / \mathrm{Ti}$ and $\mathrm{Ca} / \mathrm{Ti}$ represent the negative direction (Fig. 7). Titanium and $\mathrm{Zr} / \mathrm{Rb}$ register the highest loadings. Thus, the positive direction of this second component is associated with detrital fluxes portraying a terrigenous pool whereas the negative direction reflects processes responsible for carbonate precipitation and supposedly post-depositional processes. PC 3 explain $10 \%$ of the total variance and is represented by Fe/Ti and ARM. The other variables reflect $32 \%$ of the total variance. In summary, variations in $\mathrm{PC} 1$ could be interpreted as reflecting changes in water and sediment chemistry whereas the positive direction of PC 2 suggests a detrital input, which might be related to processes affecting the catchment such as runoff regime, vegetation cover and soil changes.

Within the dispersal of the selected elements, we identified clusters corresponding to each lithological unit, suggesting that the visual identification of sedimentological features has a clear counterpart in the numerical analyses (Fig. 7). Lithological unit I for example is developed mainly along the positive direction of PC2, lithological units II and IV are spread along both components while lithological unit III is represented along the positive direction of PC1. The development of lithological unit I, II and IV, spanning between 6030 - $2500 \mathrm{cal}$ yr BP and 1200 to present (AD 2014), alongside component 1 represented by internal processes and component 2 linked with terrigenous input indicate the transition from a system dominated by external detrital fluxes to mainly syn- and post-depositional processes within the water column and sediments. 
To assess the variability of main geochemical elements $(\mathrm{Si}, \mathrm{K}, \mathrm{Ca}, \mathrm{Ti}, \mathrm{Mn}, \mathrm{Fe}, \mathrm{Rb}, \mathrm{Zr}$ ) for each lithological unit the coefficient of variance has been calculated (Table 4). In unit I the coefficient of variance is moderate (24.4\%) with main contribution from $\mathrm{Ca}, \mathrm{Mn}, \mathrm{Zr}$ and decreasing to $22.6 \%$ and respectively, $22.5 \%$ in units II and III where again $\mathrm{Ca}, \mathrm{Mn}$ and also $\mathrm{Zr}$ bring the highest contribution. Lithological unit IV is characterized by the highest coefficient of variance (27.1\%) where Ti and Ca bring the highest contribution.

To evaluate the source of specific geochemical elements a Pearson correlation was applied. Therefore, along the entire profile, Si matches very well $\mathrm{K}$ with $\mathrm{R}^{2}$ equal to 0.88 (Fig. 8). Therefore, Si can be used as a tracer for detrital sources, even though this element is also an indicator of biological activity, particularly of siliceous algae. On the other hand, the correlation between Fe and $\mathrm{Ti}$ is weak $\left(\mathrm{R}^{2}=0.26\right)$, but still highlights the relation between Fe and detrital sources (Fig. 8). A very weak correlation was observed between $\mathrm{Ca}$ and $\mathrm{Ti}\left(\mathrm{R}^{2}=0.02\right)$ in lithological unit III (2500-1250 cal yr BP) (Fig. 9).

A strong correlation is also visible between low-field magnetic susceptibility $\left(\chi_{\mathrm{lf}}\right)$, a parameter used to estimate the magnetite concentration (Thompson and Oldfield, 1986) and total magnetic minerals capable of remanences, and SIRM where $\mathrm{R}^{2}$ equals 0.8 (Fig. 10). Data points belonging to lithological units I and III fall outside the correlation line and are detached as clusters whereas data points within lithological units II and III are clustering in the middle of the scatter plot. The correlation between magnetic mineral grain-size parameter expressed as ARM/SIRM (Geiss et al., 2003) and total magnetic concentration $\chi$ lf highlights the association between mineral magnetic grain-sizes (single stable domain - SSD, pseudo-single domain - PSD) and lithological units (Fig. 10).

\section{Discussion}

\subsection{Sediment properties}

Given the dominating karst bedrock and the observed seasonal fluctuations in lake level, it is likely that Lake Ighiel is particularly sensitive to the seasonal hydrological regime expressed as sediment flux via in-wash and groundwater inflow.

\subsubsection{The geochemical signal of detrital inputs}

A series of lithogenic elements including $\mathrm{Ti}, \mathrm{K}, \mathrm{Rb}$, and $\mathrm{Zr}$, are commonly considered indicators of watershed erosion (Koinig et al., 2003). In Lake Ighiel, the correlation between silica ( $\mathrm{Si})$ and potassium $(\mathrm{K})\left(\mathrm{R}^{2}=0.88\right)$ (Fig. 8) suggests that $\mathrm{Si}$ predominantly reflects the detrital flux. Therefore, $\mathrm{Ti}$ in particular, but also $\mathrm{K}$ and $\mathrm{Si}$, follow the same pattern in Lake Ighiel and are suitable proxies in reconstructing changes that have affected the lake environment with regard to slope in-wash 
processes. Zirconium is commonly associated with silt and coarser fractions whereas $\mathrm{Rb}$ is mainly enriched in finer, clay fractions (Kylander et al., 2013, 2011). Therefore, the $\mathrm{Zr} / \mathrm{Rb}$ ratio will reflect the deposition of coarser grains and is used here as an indirect grain-size proxy. We observe increased detrital fluxes and coarser grain sizes dominating the first phase of lacustrine sedimentation spanning between 6000 and $5000 \mathrm{cal} \mathrm{yr} \mathrm{BP}$ and a variable trend over the rest of the profile interrupted by peaks which are mainly linked with high-energy erosional (likely hydrologically-driven) events.

\subsubsection{Carbonate precipitation and organic matter}

Calcium in lake sediments predominantly reflects carbonate minerals, which can be either of endogenic (calcite) or detrital (e.g. calcite, dolomite) origin. As the bedrock in the Ighiel catchment is limestone dominated, at least some portion of the carbonate pool must be detrital. The correlation between Ti and Ca in the time intervals from $6030-2500$ cal $\mathrm{yr}$ BP $\left(\mathrm{R}^{2}=\right.$

\subsubsection{Redox conditions and changes in trace metals $\mathrm{Mn}, \mathrm{Fe}$}

Manganese (Mn) and iron (Fe) are sensitive to geochemical changes in the depositional environment so that the $\mathrm{Mn} / \mathrm{Fe}$ ratio is often used as a proxy for paleo-redox conditions (Cunningham et al., 2013; Davison, 1993; Koinig et al., 2003; Naeher et al., 2013). Manganese is highly insoluble in the water column in oxygenated conditions and consequently elevated iron and manganese $(\mathrm{Mn} / \mathrm{Fe})$ ratio depicts an oxygen-rich environment, whereas low $\mathrm{Mn} / \mathrm{Fe}$ ratios reflect more oxygendepleted conditions at the water/sediment interface. Given the size of the lake in discussion, an alternative mechanism to explain the changes in $\mathrm{Mn} / \mathrm{Fe}$ could be lake level variations, which might have increased bottom-water oxygen availability;

\subsubsection{Environmental magnetism}

The bi-plot between inferred magnetic mineral grain-size (ARM/SIRM) and total concentration of magnetic minerals

$\left(\chi_{\text {If }}\right)$ (Fig. 10) together with the S300 trend, help to trace the contribution of each magnetic domain and infer the main type of 
magnetic carriers in each lithological unit. Higher values of the ARM/SIRM ratio usually indicate the presence of singledomain magnetite grains, most probably originating from magnetotactic bacterial activity (Geiss et al., 2003). In the interval spanning between 6030 and 4200 cal yr BP (unit I), the presence of stronger-magnetic minerals (e.g. presumably haematite), with grain sizes lower than $0.1 \mu \mathrm{m}$, suggest that the main source of magnetic minerals is via weathering and surface erosion. This interpretation is confirmed by the similarity with trends in the terrigenous elements ( $\mathrm{Ti}, \mathrm{K}, \mathrm{Si}$ ) (Fig. 6). On the contrary, between 4200 and $1250 \mathrm{cal} \mathrm{yr}$ BP (units II, III) the inferred presence of magnetite with grain-sizes higher than $0.1 \mu \mathrm{m}$ is likely related to in-lake processes such as authigenesis (Lascu and Plank, 2013). The interval $1250 \mathrm{cal}$ yr BP to recent (AD 2014) (unit IV) exhibits values in both domains and therefore the magnetic mineral assemblages here can be regarded as derived from both external and internal sources.

\subsection{Climatic versus anthropogenic driven changes in lacustrine dynamics}

Sediment fluxes into a lake are mediated by natural and anthropogenic activities; consequently, before attempting any palaeoclimatic interpretation it is necessary to determine the past human influences on catchment dynamics. We use information about past vegetation composition, which may also reflect human activities in the wider area, from records within the Apuseni Mts., located near Ighiel (Feurdean et al., 2013a). These pollen data show only weak human activities prior to 3500 cal yr BP, whereas grazing, pasturing and cultivation strongly intensified during the Dacian-Roman Period, around $2000 \mathrm{cal}$ yr BP. Most intensive anthropogenic activities are observed during the last 500 years (Feurdean and Willis, 2008 b,c; Feurdean et al., 2008a; 2013a). Thus, the impact of such economic activities in the wider area has likely been more significant mainly over the last 2000 years (Schumacher et al., 2016). However, taking into consideration that over the studied interval we observed no direct indications of strong anthropogenic activities, we assume that most of the trends observed in our proxies are primarily governed by natural climate variability. This may be explained by the position of the lake in the montane forest belt with steep slopes and, due to the limestone geology, with sinkholes, dry valleys and escarpments, which are less suitable for agriculture. Nevertheless, pastoral activities might have been undertaken in the upper part of the catchment (as is currently the case) albeit the impact of these activities on catchment sediment dynamics appears to have been minimal.

Pollen records (Feurdean et al., 2013 a,b; Feurdean and Willis, 2008b,c; Feurdean et al., 2008a) on the other hand show that main components of the regional forest underwent important natural changes from a Carpinus betulus dominated woodland to a Fagus sylvatica and Abies alba mix during the last 6000 years (Feurdean et al., 2013a). Most probably such 
canopy changes over the catchment area would have had a direct impact on the sediment properties of Lake Ighiel, an issue to be further explored when the palaeoecological dataset is fully available.

\subsection{Lake Ighiel palaeohydrological record in relation to past climatic variability in the Romanian Carpathians}

Statistical analyses of sedimentological data allow the characterisation and identification of main processes that controlled the changes in lake sedimentation (Error! Reference source not found.). To further investigate the regional aspects of our interpretation, we compared our proxy data with past climatic characteristics inferred from existing palaeoclimate archives in the Carpathians.

\subsubsection{0-4200 cal yr BP}

The first part in lake sedimentation (6030 - $5000 \mathrm{cal} \mathrm{yr} \mathrm{BP)} \mathrm{is} \mathrm{characterised} \mathrm{by} \mathrm{the} \mathrm{highest} \mathrm{terrigenous} \mathrm{input} \mathrm{and} \mathrm{together}$ with the increased frequency of sand-gravel layers portrays an unstable catchment affected by erosional activity (Fig. 6). This might be interpreted as the initial lake phase when the karst-related hydrological system draining into the Ighiel basin developed. This would be in agreement with evidence of increased moisture and water availability in the Carpathian region at that time. The lake levels of Lake St. Anna (Magyari et al., 2009) (Eastern Carpathians) and Lake Brazi (Southern Carpathians) (Buczko et al., 2013) increased and enhanced fluvial activity is reported from Transylvania (Persoiu, 2010) and the Lower Danube area (Howard et al., 2004). Also, in lake Ighiel the low ARM/SIRM and S300 values suggest that main contribution of magnetic minerals is via rock weathering and surface erosion (Dearing, 1999) supporting increased sediment flux into the Ighiel basin. Pollen-based temperature reconstructions from peat profiles located approximately $150 \mathrm{~km}$ north of Lake Ighiel, indicate cold conditions with a $2^{\circ} \mathrm{C}$ decline in mean annual temperature and $3{ }^{\circ} \mathrm{C}$ fall in the mean temperature of the coldest month (Feurdean et al., 2008a).

Around 5500 and $4600 \mathrm{cal} \mathrm{yr} \mathrm{BP}$, the increase in ARM/SIRM values, from 0.02 to $0.1 \mu \mathrm{m}$ and the slight reduction in detrital input (Fig. 6) might indicate a change in the source of magnetic minerals under more stable in-lake geochemical conditions. This first excursion observed in pollen behaviour corresponds to a short lived event, with slightly warmer temperatures than at present, identified in pollen-based reconstructions from Molhasul Mare bog, NW Romania (Feurdean and Willis, 2008 b,c) which suggests temporary catchment stabilisation and vegetation development under warmer conditions. The sharp increase in carbonate content starting around $5000 \mathrm{cal}$ yr BP may be explained by the establishment of 
a permanent connection of the lacustrine environment with underground springs (e.g., karst conduits, as observed today) and/or the expansion of Carpinus betulus and subsequent changes in soil chemistry.

Between 5000 and 4200 cal yr BP, terrigenous input declined, accompanied by an increase in fine grain-size fractions

(Fig. 6), suggesting progressive catchment slopes stabilisation and a decline in erosional activity. At around 4200 cal yr BP detrital flux increased again probably due to enhanced surface runoff processes. This is in agreement with several other changes in the region including increased fluvial activity in the Lower Danube area (Howard et al., 2004), a decline in biomass burning reflecting wetter conditions in central Romania (Feurdean et al., 2013b), a change (thinning) in timberline in the Northern Carpathians (Feurdean et al., 2016) and low $\delta^{18} \mathrm{O}$ and $\delta^{13} \mathrm{C}$ values in a speleothem from Ursilor Cave interpreted as cold and wet conditions (Onac et al., 2002).

\subsubsection{0-2500 cal yr BP}

The lithological changes from homogeneous to faintly laminated sediments between 4200 and $2500 \mathrm{cal} \mathrm{yr} \mathrm{BP}$, together with a lower sedimentation rate and moderate variability in geochemical proxies, portray a transitional phase in lacustrine dynamics towards more stable conditions (Fig. 6). From $4200 \mathrm{cal}$ yr BP, the slight increase in organic matter content and the appearance of chrysophyte cysts together with changes in $\mathrm{Mn} / \mathrm{Fe}$ suggest increased biological productivity in a more oxygenated water column. The peaks in detrital proxies around 3600 and $3300 \mathrm{cal}$ yr BP (Fig. 6) are attributed to runoff events. These events took place during the same two time periods for which a precipitation increase of $\sim 100 \mathrm{~mm}$ has been reconstructed from the Preluca Tiganului peat-bog record (NW Carpathians) (Feurdean et al., 2008a). Higher water tables during these time intervals were also reported from the nearby Varatec peatbog record (Schnitchen et al., 2006) and even biomass burning in the Transylvanian lowlands was reduced at that time (Feurdean et al., 2013b).

\subsubsection{0-1200 cal yr BP}

The sedimentological change at $2500 \mathrm{cal}$ yr BP marked by the increased frequency of organic detritus rich layers as confirmed by elevated OM contents along with reduced terrigenous inputs, increased abundance of diatoms between 2500 and $1200 \mathrm{cal}$ yr BP indicate decreased catchment erosion and increased lacustrine productivity (Fig. 6). Carbonate contents show a similar trend with organic matter $\left(\mathrm{R}^{2}=0.42\right)$ suggesting carbonate is at least partly related to biological productivity. Oscillating $\mathrm{Mn} / \mathrm{Fe}$ ratios suggest fluctuations in oxic conditions of the deep water. 
subaquatic mosses suggest either rapid burial or a poorly oxygenated lake bottom which would have prevented rapid 419 decomposition. The drastic drop in detrital proxies between 2200-1400 cal yr BP indicates low erosion. After this period of low erosion during the Roman Warm Period (RWP) terrigenous input increased again between 1400-1100 cal yr BP coinciding with Dark Age Cold Period, a period characterised by seasonally increasing rainfall as found also in high-altitude records from NE Romania (Cristea et al., 2013; Feurdean et al., 2015). In the lowlands this period has been described as one of the most active period in flood-plain river dynamics of the entire Holocene (Chiriloaei et al., 2012).

\subsubsection{Last 1200 years}

The interval from $1200 \mathrm{cal}$ yr BP to the present (coring date in AD 2014) is characterised by a lithological change from brown-red laminated clays to light-brown homogenous clays (Fig. 6). Detrital elements describe a decreasing trend, with low values between 1000 and $700 \mathrm{cal} \mathrm{yr} \mathrm{BP}$, and a peak around $150 \mathrm{cal} \mathrm{yr} \mathrm{BP}$ reflecting a $6 \mathrm{~cm}$ thick turbidite. The first time the region (Feurdean et al., 2015; Popa and Kern, 2009).

The following interval spanning from 700 to $250 \mathrm{cal}$ yr BP is characterised by attenuated variations in proxy data suggesting low amplitude changes in the lake basin with low levels of erosional activity (Fig. 6). This interval coincides with the Little Ice Age (LIA), a period characterised by a decrease in mean annual temperatures also identified in multi-proxy reconstructions (Haliuc et al., 2016), carbon isotope excursion (Cristea et al., 2013) and tree ring growth (Popa and Kern, 2009) from Northern Carpathians and could explain the reduced catchment erosion at predominantly dry conditions. The top

\subsection{Lake Ighiel multi-proxy record in a regional context}

In order to apply the Ighiel proxy data for better constraining past environments in the Carpathian region, we compare our results with palaeoclimatic and palaeohydrological reconstructions across Central Europe (CE) and the Balkans. The aim of these comparisons is to test for the so-called see-saw hydro-climatic gradients which are thought to act on short spatial and temporal scales throughout the Holocene (Davis and Brewer, 2009). The winter and summer latitudinal temperature gradient 
(LTG) as defined by Davis and Brewer (2009), an index highly underestimated by modelling experiments (Mauri et al., 2014), appears crucial in driving hydrological changes across the Carpathians. It has been shown that during the Holocene the winter and summer LTG influence the AO index (regionally expressed as NAO) and drive anomalous wetter/drier conditions over the north-eastern Mediterranean and central-eastern Europe (Davis and Brewer, 2009; Zhang et al., 2014). Instrumental observation proves that the recent seasonal climatic variability in Romania is largely linked to changes in large-scale atmospheric circulation expressed as NAO, AMO and blocking phenomena (Busuioc et al., 2015; Ionita et al., 2013; Tomozeiu et al., 2005, 2002) and it may be assumed that their influence extended even further back in time.

Figures 11 compares the terrigenous input and $\mathrm{Mn} / \mathrm{Fe}$ ratios from Lake Ighiel with reconstructed erosional activity in the Balkan region/NE Mediterranean (Morellon et al., 2016; Wagner et al., 2010), past flood activity in the northern Alpine foreland (Czymzik et al., 2013; Swierczynski et al., 2013), flood activity north and south of the Alps (Wirth et al., 2013), lake level variations for central-western Europe (Magny, 2004), and flood activity (Starkel, 2002) in Central Europe. This allows us to track palaeohydrological changes for the last 6000 years along a $700 \mathrm{~km} \mathrm{NW-SE} \mathrm{transect} \mathrm{from} \mathrm{the} \mathrm{Alps,} \mathrm{to} \mathrm{the} \mathrm{Balkan}$ Peninsula ((Fig. 1). To further infer possible forcing mechanisms for hydrological changes, total solar irradiance (TSI) (Steinhilber et al., 2009) and NAO index reconstructions from Greenland (Olsen et al., 2012) are also shown.

The increased detrital flux which characterise Lake Ighiel between 6030 and 5000 cal yr BP parallels a period of increased flood activity reconstructed from the Lake Mondsee record (Swierczynski et al., 2013) (Fig. 11), as well as a period of increased humidity in the NE Mediterranean (Finné et al., 2011; Lacey et al., 2014) and elevated lake levels and enhanced fluvial activity in CE Europe (Leng et al., 2013; Magny, 2004; Starkel, 2002). This regional correspondence suggests increased precipitation over large parts of Europe and a common forcing mechanism predominantly connected with the Atlantic atmospheric mode. An increasing influence of the Atlantic-derived moisture sources for the Carpathian area around the mid-Holocene has also been recorded in speleothem data (see review in Drăguşin et al., 2014) where a clear shift in isotopic data is observed.

The transition from clayey to more organic sediments in Lake Ighiel from 4500 to $4200 \mathrm{cal} \mathrm{yr}$ BP, accompanied by an increase in erosional activity is concomitant with increasing flood activity in Lake Mondsee, NE Alps (Swierczynski et al., 2013) and over the Balkans (Francke et al., 2013; Wagner et al., 2010) (Fig. 11). This is in agreement with the negative summer and winter LTG (Davis and Brewer, 2009) that might have caused wetter conditions at the mid-to-late Holocene transition (Walker et al., 2012). This period marks the end of a generally positive NAO-type circulation towards a more variable index with increasing occurrences of NAO-phases (Magny et al., 2013; Olsen et al., 2012). Interestingly, this change 
coincides with the precessional insolation shift at $60^{\circ} \mathrm{N}$ (Berger and Loutre, 1991) when the decreased contrast between December/June insolation reached its half point. The gradual decrease in insolation and LTG (Magny et al., 2013) might have driven a non-linear climatic response likely reflected by the transitional lithological change in the Lake Ighiel sediment record.

The flood frequency records from lake sediments north of the Alps (Czymzik et al., 2013; Swierczynski et al., 2013) denote a first increase in extreme hydro-meteorological events in central Europe between 4200 and 2500 cal yr BP. On the contrary, in the Balkan region decreased moisture availability was documented (Fouache et al., 2010; Lacey et al., 2014; Leng et al., 2013; Morellon et al., 2016; Zanchetta et al., 2012). However, in Lake Ighiel, we observe during this time the highest incidence of centennial-scale periods of increased detrital influx in the entire profile (Fig. 11). This interval partly overlaps with an increased fluvial activity and high lake levels in CE Europe (Magny, 2004; Starkel, 2002). The correspondence between increased detrital sedimentation in Lake Ighiel and higher moisture in central Europe (Alps) points to a common hydrological regime. These wetter conditions in the Alps and the Carpathians are in contrast to a drier climate in the Balkans, suggesting a strong NW-SE hydro-climatic gradient at that time.

The predominantly autochthonous organic and less detrital sedimentation in Lake Ighiel between 2500 and $1250 \mathrm{cal} \mathrm{yr}$ BP indicates a generally low erosional activity in the Carpathians, which overlaps with other reconstructions from the region where slightly decreasing moisture availability is observed (Schnitchen et al. 2002). This is in agreement with the positive NAO phase that might have been responsible for reduced precipitation in the region. The pattern is interrupted at around $2500 \mathrm{cal}$ yr BP by two short-lived intervals of a moderate increase in catchment erosion (Fig. 11) which correspond to increased frequency in flood activity in the NE Alps (Wirth et al., 2013), higher incidence of hydrological events in the Ammersee record (Czymzik et al., 2013), high lake levels (Magny, 2004) and overall increased flood activity in CE Europe (Starkel, 2002), a period of low flood activity in Lake Mondsee (Swierczynski et al., 2013). However, these events of increased erosional activity contrasts with the warm although moist conditions recorded by the Balkan lake records of Butrint (Morellon et al., 2016), Skhodra (Zanchetta et al., 2012), Maliq (Fouache et al., 2010) and Ohrid (Lacey et al., 2014). However, summer and winter LTG fails to explain the regional hydrological changes and do not account for reduced moisture availability in the region (Zhang et al., 2014). A possible explanation for this pattern observed during the last 3000 years might be the increased regional temperatures and the intensified anthropogenic activities which start to play an important role in hydrological regimes and even potentially obscure the influence of atmospheric moisture availability as shown in the Balkan records (Zhang et al., 2014). 

Anomaly (MCA) (Fig. 11), a period characterised by annual average temperature increase of about $1-2^{\circ} \mathrm{C}$ and reduced rainfall amount over NW Europe (Lamb, 1965), but divergent hydrological conditions in the Mediterranean region (Roberts et al., 2012). Interestingly, more wetter conditions were reconstructed for the Western Balkans at the time (Lacey et al., 2014; Leng et al., 2013), whereas in eastern Balkans (Zhang et al., 2014) a more negative water balance is documented. The Lake Ighiel record also shows decreased runoff suggesting overall drier conditions between 700 and 250 cal yr BP (LIA) in line with the inferred hydrological change visible in eastern Balkans and also in other reconstructions from the Carpathians (see Section 5.3), but in contrast with the Alps (Wirth et al., 2013), observation that suggests a strong NW-SE hydrological gradient. Although it is suggested that the dominant circulation mode over the CE Europe during mid-Holocene is the

Atlantic, the instrumental and pre-instrumental data show that extreme events in the alpine foreland are strongly controlled by the SW Alps (Wilhelm et al., 2016). It is likely that although the Atlantic circulation is dominant over the study area, the

\section{Conclusions}

Our multi-proxy data obtained from Lake Ighiel's sedimentary record reaching 6000 years back in time revealed new insights into local, predominantly hydrologically-driven catchment dynamics which are discussed in the frame of regional hydrological changes in the western Romanian Carpathians (CE Europe). Thereby, we contribute with a new record in sensitive region which is critical for understanding past shifts in hydrological gradients in Europe in the past.

The influence of hydro-climatic gradients is assessed with reference to winter and summer LTGs. We show that between 6030 and $5000 \mathrm{cal}$ yr BP the enhanced runoff and sediment transport processes at Lake Ighiel are consistent with generally high moisture availability in CE Europe and the NE Mediterranean probably driven by decrease of summer and winter LTG. Likely, this was the time when the current atmospheric circulation pattern with the Atlantic as the main moisture source for the Carpathians was established. Probably, the establishment of this atmospheric change even initiated the formation of Ighiel as a lake. A similar pattern is observed at the transition between mid and late Holocene spanning 4500 to $4200 \mathrm{cal} \mathrm{yr}$ BP. The high incidence of multi-century detrital events, visible at Lake Ighiel between 4200 and $2500 \mathrm{cal}$ yr BP, is in agreement with records of flood activity in central Europe (the Alps), but contrasts with drier conditions in the NE Mediterranean. This indicates that central Europe (Alps) and the Carpathians were linked through common moisture sources, probably the 
Atlantic, but with seasonal Mediterranean connections although mediated by a significant NW-SE hydro-climatic gradient. During the last 3000 years, the hydrological pattern of Lake Ighiel seems to be connected with a different atmospheric mode than before, but is in agreement with a regionally wetter climate interrupted by dry spells. Our results contribute to the understanding of mid and late Holocene palaeohydrological changes in the Carpathians, demonstrating the implications of summer and winter LTG in hydrological variability.

\section{Acknowledgments:}

This is a contribution to project PN-II-ID-PCE-2012-4-0530 "Millennial-scale geochemical records of anthropogenic impact and natural climate change in the Romanian Carpathians" contract nr. 15/02.09.2013. The authors thank both Romsilva and Administratia Siturilor Natura 2000 Trascău for granting access to the site; Frantiuc Alexandru for help drafting the maps; Ioan Lascu for useful suggestions and Geza Rajka for logistical support.

\section{References:}

Akinyemi, F.O., Hutchinson, S.M., Mîndrescu, M., Rothwell, J.J., 2013. Lake sediment records of atmospheric pollution in the Romanian Carpathians. Quat. Int. 293, 105-113. doi:10.1016/j.quaint.2012.01.022

Berger, A., Loutre, M.F., 1991. Insolation values for the climate of the last 10 million years. Quat. Sci. Rev. 10, $297-317$. doi:10.1016/0277-3791(91)90033-Q

Blaauw, M., Christen, J.A., 2013. Bacon manual - v2.2.

Bojariu, R., Giorgi, F., 2005. The North Atlantic Oscillation signal in a regional climate simulation for the European region. Tellus A 641-653. doi:10.3402/tellusa.v57i4.14709

Bojariu, R., Paliu, D.-M., 2001. North Atlantic Oscillation Projection on Romanian Climate Fluctuations in the Cold Season. Detect. Model. Reg. Clim. Chang. Assoc. Impacts.

Brauer, A., Casanova, J., 2001. Chronology and depositional processes of the laminated sediment record from Lac d'Annecy, French Alps. J. Paleolimnol. 25, 163-177. doi:10.1023/A:1008136029735

Braun, M., Hubay, K., Magyari, E., Veres, D., Papp, I., Bálint, M., 2013. Using linear discriminant analysis (LDA) of bulk lake sediment geochemical data to reconstruct lateglacial climate changes in the South Carpathian Mountains. Quat. Int. 293, 114-122. doi:10.1016/j.quaint.2012.03.025

Busuioc, A., Dobrinescu, A., Birsan, M.V., Dumitrescu, A., Orzan, A., 2015. Spatial and temporal variability of climate 
Chiriloaei, F., Rădoane, M., Perşoiu, I., Popa, I., 2012. Late Holocene history of the Moldova River Valley, Romania. Catena 93, 64-77. doi:10.1016/j.catena.2012.01.008

Cohen, A.S., 2003. Paleolimnology: The History and Evolution of Lake Systems. Oxford University Press. doi:10.1669/0883-1351(2004)019<0184:BR>2.0.CO;2

Constantin, S., Bojar, A.-V., Lauritzen, S.-E., Lundberg, J., 2007. Holocene and Late Pleistocene climate in the sub-

Croudace, I.W., Rindby, a., Rothwell, R.G., 2006. ITRAX: description and evaluation of a new multi-function X-ray core scanner. Geol. Soc. London, Spec. Publ. 267, 51-63. doi:10.1144/GSL.SP.2006.267.01.04

Cunningham, L., Vogel, H., Wennrich, V., Juschus, O., Nowaczyk, N., Rosén, P., 2013. Amplified bioproductivity during Transition IV (332 000-342 $000 \mathrm{yr}$ ago): Evidence from the geochemical record of Lake El'gygytgyn. Clim. Past 9, 679-686. doi:10.5194/cp-9-679-2013

Czymzik, M., Brauer, A., Dulski, P., Plessen, B., Naumann, R., von Grafenstein, U., Scheffler, R., 2013. Orbital and solar forcing of shifts in Mid- to Late Holocene flood intensity from varved sediments of pre-alpine Lake Ammersee (southern Germany). Quat. Sci. Rev. 61, 96-110. doi:10.1016/j.quascirev.2012.11.010

Davis, B.A.S., Brewer, S., 2009. Orbital forcing and role of the latitudinal insolation/temperature gradient. Clim. Dyn. 32, 143-165. doi:10.1007/s00382-008-0480-9

Davis, B.S., Brewer, S., Stevenson, A.C., Guiot, J., 2003. The temperature of Europe during the Holocene reconstructed from pollen data. Quat. Sci. Rev. 22, 1701-1716. doi:10.1016/S0277-3791(03)00173-2

Davison, W., 1993. Iron and manganese in water. Earth-Science Rev. 34, 119-163. doi:10.2307/41226456

Dearing, J., 1999. Environmental magnetic susceptibility.Using the Bartington MS2 System, 2nd ed. Chi Publ, England.

Drăguşin, V., Staubwasser, M., Hoffmann, D.L., Ersek, V., Onac, B.P., Veres, D., 2014. Constraining Holocene hydrological changes in the Carpathian-Balkan region using speleothem $\delta 180$ and pollen-based temperature reconstructions. Clim. Past 10, 1363-1380. doi:10.5194/cp-10-1363-2014 
Fărcaş, S., Tanţău, I., Mîndrescu, M., Hurdu, B., 2013. Holocene vegetation history in the Maramureş Mountains (Northern Romanian Carpathians). Quat. Int. 293, 92-104. doi:10.1016/j.quaint.2012.03.057

Feurdean, A., Klotz, S., Mosbrugger, V., Wohlfarth, B., 2008a. Pollen-based quantitative reconstructions of Holocene climate variability in NW Romania. Palaeogeogr. Palaeoclimatol. Palaeoecol. 260, 494-504. doi:10.1016/j.palaeo.2007.12.014

Feurdean, A., Willis, K.J., 2008b. The usefulness of a long-term perspective in assessing current forest conservation management in the Apuseni Natural Park, Romania. For. Ecol. Manage. 256, 421-430. doi:10.1016/j.foreco.2008.04.050

Feurdean, A., Willis, K.J., 2008c. Long-term variability of Abies alba in NW Romania: implications for its conservation management. Divers. Distrib. 14, 1004-1017. doi:10.1111/j.1472-4642.2008.00514.x

Feurdean, A., Parr, C.L., Tantau, I., Farcas, S., Marinova, E., Persoiu, I., 2013a. Biodiversity variability across elevations in the Carpathians: Parallel change with landscape openness and land use. The Holocene 23, 869-881. doi: $10.1177 / 0959683612474482$

Feurdean, A., Liakka, J., Vannière, B., Marinova, E., Hutchinson, S.M., Mosburgger, V., Hickler, T., 2013b. 12,000-Years of fire regime drivers in the lowlands of Transylvania (Central-Eastern Europe): a data-model approach. Quat. Sci. Rev. 81, 48-61. doi:10.1016/j.quascirev.2013.09.014

Feurdean, A., Perşoiu, A., Tanţău, I., Stevens, T., Magyari, E.K., Onac, B.P., Marković, S., Andrič, M., Connor, S., Fărcaş, S., Gałka, M., Gaudeny, T., Hoek, W., Kolaczek, P., Kuneš, P., Lamentowicz, M., Marinova, E., Michczyńska, D.J., Perşoiu, I., Płóciennik, M., Słowiński, M., Stancikaite, M., Sumegi, P., Svensson, A., Tămaş, T., Timar, A., Tonkov, S., Toth, M., Veski, S., Willis, K.J., Zernitskaya, V., 2014. Climate variability and associated vegetation response throughout Central and Eastern Europe (CEE) between 60 and 8 ka. Quat. Sci. Rev. doi:10.1016/j.quascirev.2014.06.003

Feurdean, A., Galka, M., Kuske, E., Tantau, I., Lamentowicz, M., Florescu, G., Liakka, J., Hutchinson, S.M., Mulch, A., Hickler, T., 2015. Last Millennium hydro-climate variability in Central-Eastern Europe (Northern Carpathians, Romania). The Holocene 25, 1179-1192. doi:10.1177/0959683615580197

Feurdean, A., Gałka, M., Tanţău, I., Geantă, A., Hutchinson, S.M., Hickler, T., 2016. Tree and timberline shifts in the northern Romanian Carpathians during the Holocene and the responses to environmental changes. Quat. Sci. Rev. 134, 100-113. doi:10.1016/j.quascirev.2015.12.020 
613

614

615

616

617

618

619

620

621

622

623

624

625

626

627

628

629

630

631

632

633

634

635

636

637

638

639

640

Finné, M., Holmgren, K., Sundqvist, H.S., Weiberg, E., Lindblom, M., 2011. Climate in the eastern Mediterranean, and adjacent regions, during the past 6000 years - A review. J. Archaeol. Sci. 38, 3153-3173. doi:10.1016/j.jas.2011.05.007

Finsinger, W., Kelly, R., Fevre, J., Magyari, E.K., 2014. A guide to screening charcoal peaks in macrocharcoal-area records for fire-episode reconstructions. The Holocene 24, 1002-1008. doi:10.1177/0959683614534737

Fouache, E., Desruelles, S., Magny, M., Bordon, A., Oberweiler, C., Coussot, C., Touchais, G., Lera, P., Lezine, A.M., Fadin, L., Roger, R., 2010. Palaeogeographical reconstructions of Lake Maliq (Korca Basin, Albania) between 14,000 BP and 2000 BP. J. Archaeol. Sci. 37, 525-535. doi:10.1016/j.jas.2009.10.017

Francke, A., Wagner, B., Leng, M.J., Rethemeyer, J., 2013. A Late Glacial to Holocene record of environmental change from Lake Dojran (Macedonia, Greece). Clim. Past 9, 481-498. doi:10.5194/cp-9-481-2013

Gałka, M., Tanţău, I., Ersek, V., Feurdean, A., 2016. A 9000year record of cyclic vegetation changes identified in a montane peatland deposit located in the Eastern Carpathians (Central-Eastern Europe): Autogenic succession or regional climatic influences? Palaeogeogr. Palaeoclimatol. Palaeoecol. 449, 52-61. doi:10.1016/j.palaeo.2016.02.007

Geiss, C.E., Umbanhowar, C.E., Camill, P., Banerjee, S.K., 2003. Sediment magnetic properties reveal Holocene climate change along the Minnesota prairie-forest ecotone. J. Paleolimnol. 30, 151-166. doi:10.1023/A:1025574100319

Giosan, L., Coolen, M.J.L., Kaplan, J.O., Constantinescu, S., Filip, F., Filipova-Marinova, M., Kettner, A.J., Thom, N., 2012. Early Anthropogenic Transformation of the Danube-Black Sea System. Sci. Rep. 2, 1-6. doi:10.1038/srep00582

Haliuc, A., Hutchinson, S.M., Florescu, G., Feurdean, A., 2016. The role of fire in landscape dynamics: An example of two sediment records from the Rodna Mountains, northern Romanian Carpathians. Catena 137, 432-440. doi:10.1016/j.catena.2015.10.021

Howard, A.J., Macklin, M.G., Bailey, D.W., Mills, S., Andreescu, R., 2004. Late-glacial and Holocene river development in the Teleorman Valley on the southern Romanian Plain. J. Quat. Sci. 19, 271-280. doi:10.1002/jqs.805

Hurrell, J.W., Kushnir, Y., Otterson, G., Visbeck, M., 2003. An overview of the North Atlantic Oscillation. The North Atlantic Oscillation - Climatic Significance and Environmental Impact. Geophys. Monogr. $134,263$. doi:10.1029/GM134

Hutchinson, S.M., 1995. Use of magnetic and radiometric measurements to investigate erosion and sedimentation in a British upland catchment. Earth Surf. Process. Landforms 20, 293-314. doi:10.1002/esp.3290200402

Jull A.J.T., Burr G.S., Beck J.W., Hodgins G.W.L., Biddulph D.L., Gann J., Hatheway A.L., Lange T.E., Lifton N.A., 2006. Application of accelerator mass spectrometry to environmental and paleoclimate studies at the University of Arizona. 
Radioactivity in the Environment 8:3-23.

642

Ionita, M., Rimbu, N., Chelcea, S., Patrut, S., 2013. Multidecadal variability of summer temperature over Romania and its relation with Atlantic Multidecadal Oscillation. Theor. Appl. Climatol. 113, 305-315. doi:10.1007/s00704-012-0786-8

Koinig, K., Shotyk, W., Lotter, A., Ohlendorf, C., 2003. 9000 Years of Geochemical Evolution of Lithogenic Major and Trace Elements in the Sediment of an alpine lake. J. Paleolimnol. 4, 307-320.

Kylander, M.E., Ampel, L., Wohlfarth, B., Veres, D., 2011. High-resolution X-ray fluorescence core scanning analysis of Les Echets (France) sedimentary sequence: New insights from chemical proxies. J. Quat. Sci. 26 , $109-117$. doi:10.1002/jqs. 1438

Lacey, J.H., Francke, A., Leng, M.J., Vane, C.H., Wagner, B., 2014. A high-resolution Late Glacial to Holocene record of environmental change in the Mediterranean from Lake Ohrid (Macedonia/Albania). Int. J. Earth Sci. 104, $1623-1638$. doi:10.1007/s00531-014-1033-6

Lamb, H.H., 1965. The Early Medieval Warm Epoch and its sequel. Palaeogeogr. Palaeoclimatol. Palaeoecol. 1, $13-37$.

Magny, M., 2004. Holocene climate variability as reflected by mid-European lake-level fluctuations and its probable impact on prehistoric human settlements. Quat. Int. 113, 65-79. doi:10.1016/S1040-6182(03)00080-6

Magny, M., Combourieu-Nebout, N., De Beaulieu, J.L., Bout-Roumazeilles, V., Colombaroli, D., Desprat, S., Francke, A., Joannin, S., Ortu, E., Peyron, O., Revel, M., Sadori, L., Siani, G., Sicre, M.A., Samartin, S., Simonneau, A., Tinner, W., Vannière, B., Wagner, B., Zanchetta, G., Anselmetti, F., Brugiapaglia, E., Chapron, E., Debret, M., Desmet, M., Didier, J., Essallami, L., Galop, D., Gilli, A., Haas, J.N., Kallel, N., Millet, L., Stock, A., Turon, J.L., Wirth, S., 2013. North-south palaeohydrological contrasts in the central mediterranean during the holocene: Tentative synthesis and working hypotheses. Clim. Past 9, 2043-2071. doi:10.5194/cp-9-2043-2013

Magyari, E., Buczkó, K., Jakab, G., Braun, M., Pál, Z., Karátson, D., Pap, I., 2009. Palaeolimnology of the last crater lake in the Eastern Carpathian Mountains: a multiproxy study of Holocene hydrological changes. Hydrobiologia 631, 29-63. doi:10.1007/s10750-009-9801-1

Magyari, E.K., Kuneš, P., Jakab, G., Sümegi, P., Pelánková, B., Schäbitz, F., Braun, M., Chytrý, M., 2014. Late Pleniglacial vegetation in eastern-central Europe: Are there modern analogues in Siberia? Quat. Sci. Rev. 95, 60-79. doi:10.1016/j.quascirev.2014.04.020

Mann, M.E., 2002. Little Ice Age. Encycl. Glob. Environ. Chang. 1, 504-509.

Martin-Puertas, C., Valero-Garces, B.L., Mata, M.P., Moreno, A., Giralt, S., Martinez-Ruiz, F., Jimenez-Espejo, F., 2011. 
Geochemical processes in a Mediterranean Lake: A high-resolution study of the last 4,000 years in Zonar Lake, southern Spain. J. Paleolimnol. 46, 405-421. doi:10.1007/s10933-009-9373-0

Mauri, A., Davis, B.A.S., Collins, P.M., Kaplan, J.O., 2014. The influence of atmospheric circulation on the mid-Holocene climate of Europe: A data-model comparison. Clim. Past 10, 1925-1938. doi:10.5194/cp-10-1925-2014

Mayewski, P.A., Rohling, E.E., Curt Stager, J., Karlén, W., Maasch, K.A., David Meeker, L., Meyerson, E.A., Gasse, F., van Kreveld, S., Holmgren, K., Lee-Thorp, J., Rosqvist, G., Rack, F., Staubwasser, M., Schneider, R.R., Steig, E.J., 2004. Holocene climate variability. Quat. Res. 62, 243-255. doi:10.1016/j.yqres.2004.07.001

McDermott, F., Atkinson, T.C., Fairchild, I.J., Baldini, L.M., Mattey, D.P., 2011. A first evaluation of the spatial gradients in $\delta 180$ recorded by European Holocene speleothems. Glob. Planet. Change 79, $275-287$. doi:10.1016/j.gloplacha.2011.01.005

Meyers, P.A., Lallier-Verges, E., 1999. Lacustrine sedimentary organic matter records of Late Quaternary paleoclimates. J. Paleolimnol. 21, 345-372. doi:10.1023/A:1008073732192

Mihăiescu, R., Pop, A. I., Mihăiescu, T., Muntean, E., Beldean, S., Muntean, N., Alhafez, L., Ozunu A., 2012. Physicochemical characteristics of the karst lake Ighiu (Romania). Environ. Eng. and Manag. Journal 11, 623-626

Molnár, M., Janovics, R., Major, I., 2013a. Status Report of the New AMS 14C Sample Preparation Lab of the Hertelendi Laboratory of Environmental Studies (Debrecen, Hungary). Radiocarbon 55, 665-676. doi:10.2458/azu_js_rc.55.16394

Molnár, M., Rinyu, L., Veres, M., Seiler, M., Wacker, L., Synal, H.-A., 2013b. EnvironMICADAS: A Mini 14C AMS with Enhanced Gas Ion Source Interface in the Hertelendi Laboratory of Environmental Studies (HEKAL), Hungary. Radiocarbon 55, 338-344. doi:10.2458/azu_js_rc.55.16331

Momeu, L., Ciorca, A., László, O.T., Segedi, C., Battes, K.P., Cîmpean, M., 2015. The karstic lake Iezerul Ighiel ( Transylvania , Romania ): its first limnological study. Stud. Univ. Babes-Bolyai Biol. LX, 2 2015, 39-60.

Morellon, M., Anselmetti, F.S., Ariztegui, D., Brushulli, B., Sinopoli, G., Wagner, B., Sadori, L., Gilli, A., Pambuku, A., 2016. Human-climate interactions in the central Mediterranean region during the last millennia: The laminated record of Lake Butrint (Albania). Quat. Sci. Rev. 136, 134-152. doi:10.1016/j.quascirev.2015.10.043

Muller, J., Kylander, M., Martinez-Cortizas, A., Wüst, R.A.J., Weiss, D., Blake, K., Coles, B., Garcia-Sanchez, R., 2008. The use of principle component analyses in characterising trace and major elemental distribution in a $55 \mathrm{kyr}$ peat deposit in tropical Australia: Implications to paleoclimate. Geochim. Cosmochim. Acta 72, $449-463$. doi:10.1016/j.gca.2007.09.028 
Naeher, S., Gilli, A., North, R.P., Hamann, Y., Schubert, C.J., 2013. Tracing bottom water oxygenation with sedimentary $\mathrm{Mn} / \mathrm{Fe}$ ratios in Lake Zurich, Switzerland. Chem. Geol. 352, 125-133. doi:10.1016/j.chemgeo.2013.06.006

Nemec, M., Wacker, L., Hajdas, I., Gäggeler, H., 2010. Alternative Methods for Cellulose Preparation for Ams Measurement. Radiocarbon 52, 1358-1370.

Olsen, J., Anderson, N.J., Knudsen, M.F., 2012. Variability of the North Atlantic Oscillation over the past 5,200 years. Nat. Geosci. 5, 1-14. doi:10.1038/ngeo1589

Onac, B.P., Constantin, S., Lundberg, J., Lauritzen, S.-E., 2002. Isotopic climate record in a Holocene stalagmite from Ursilor Cave (Romania). J. Quat. Sci. 17, 319-327. doi:10.1002/jqs.685

Popa, I., Kern, Z., 2009. Long-term summer temperature reconstruction inferred from tree-ring records from the Eastern Carpathians. Clim. Dyn. 32, 1107-1117. doi:10.1007/s00382-008-0439-x

Reimer, P., 2013. IntCal13 and Marine13 Radiocarbon Age Calibration Curves 0-50,000 Years cal BP. Radiocarbon 55, 1869-1887. doi:10.2458/azu_js_rc.55.16947

Roberts, N., Moreno, A., Valero-Garcés, B.L., Corella, J.P., Jones, M., Allcock, S., Woodbridge, J., Morellón, M., Luterbacher, J., Xoplaki, E., Türkeş, M., 2012. Palaeolimnological evidence for an east-west climate see-saw in the Mediterranean since AD 900. Glob. Planet. Change 84-85, 23-34. doi:10.1016/j.gloplacha.2011.11.002

Santisteban, J.I., Mediavilla, R., López-Pamo, E., Dabrio, C.J., Blanca Ruiz Zapata, M., José Gil García, M., Castaño, S., Martínez-Alfaro, P.E., 2004. Loss on ignition: a qualitative or quantitative method for organic matter and carbonate mineral content in sediments? J. Paleolimnol. 32, 287-299. doi:10.1023/B:JOPL.0000042999.30131.5b

Schnitchen, C., Charman, D.J., Magyari, E., Braun, M., Grigorszky, I., Tóthmérész, B., Molnár, M., Szántó, Z., 2006. Reconstructing hydrological variability from testate amoebae analysis in Carpathian peatlands. J. Paleolimnol. 36, 117. doi:10.1007/s10933-006-0001-y

Schumacher, M., Schier, W., Schütt, B., 2016. Mid-Holocene vegetation development and herding-related interferences in the Carpathian region. Quat. Int. 415, 253-267. doi:10.1016/j.quaint.2015.09.074

Steinhilber, F., Beer, J., Fröhlich, C., 2009. Total solar irradiance during the Holocene. Geophys. Res. Lett. 36, L19704. doi:10.1029/2009GL040142

Swierczynski, T., Lauterbach, S., Dulski, P., Delgado, J., Merz, B., Brauer, A., 2013. Mid- to late Holocene flood frequency changes in the northeastern Alps as recorded in varved sediments of Lake Mondsee (Upper Austria). Quat. Sci. Rev. 80, 78-90. doi:10.1016/j.quascirev.2013.08.018 
Tanţău, I., Feurdean, A., De Beaulieu, J.L., Reille, M., Fărcaş, S., 2014. Vegetation sensitivity to climate changes and human impact in the Harghita Mountains (Eastern Romanian Carpathians) over the past 15000 years. J. Quat. Sci. 29, 141152. doi:10.1002/jqs.2688

Thompson, R., Oldfield, F., 1986. Environmental Magnetism. Allen\&Unwin, London. doi:10.1007/978-94-011-8036-8

Tomozeiu, R., Busuioc, A., Stefan, S., 2002. Changes in seasonal mean maximum air temperature in Romania and their connection with large-scale circulation. Int. J. Climatol. 22, 1181-1196. doi:10.1002/joc.785

Tomozeiu, R., Stefan, S., Busuioc, A., 2005. Winter precipitation variability and large-scale circulation patterns in Romania. Theor. Appl. Climatol. 81, 193-201. doi:10.1007/s00704-004-0082-3

Tribovillard, N., Algeo, T.J., Lyons, T., Riboulleau, A., 2006. Trace metals as paleoredox and paleoproductivity proxies: An update. Chem. Geol. 232, 12-32. doi:10.1016/j.chemgeo.2006.02.012

Veres, D., 2002. A Comparative Study Between Loss on Ignition and Total Carbon Analysis on Mineralogenic Sediments. Stud. UBB, Geol. XLVII, 171-182.

Veres, D., Lallier-Verges, E., Wohlfarth, B., Lacourse, T., Keravis, D., Bjorck, S., Preusser, F., Andrieu-Ponel, V., Ampel, L., 2009. Climate-driven changes in lake conditions during late MIS 3 and MIS 2: A high-resolution geochemical record from Les Echets, France. Boreas 38, 230-243. doi:10.1111/j.1502-3885.2008.00066.x

Wagner, B., Vogel, H., Zanchetta, G., Sulpizio, R., 2010. Environmental change within the Balkan region during the past ca. 50 ka recorded in the sediments from lakes Prespa and Ohrid. Biogeosciences 7, 3187-3198. doi:10.5194/bg-7-31872010

Walker, M.J.C., Berkelhammer, M., Björck, S., Cwynar, L.C., Fisher, D.A., Long, A.J., Lowe, J.J., Newnham, R.M., Rasmussen, S.O., Weiss, H., 2012. Formal subdivision of the Holocene Series/Epoch: a Discussion Paper by a Working Group of INTIMATE (Integration of ice-core, marine and terrestrial records) and the Subcommission on Quaternary Stratigraphy (International Commission on Stratigraphy). J. Quat. Sci. 27, 649-659. doi:10.1002/jqs.2565

Wilhelm B., Vogel H., Crouzet C., Etienne D. and Anselmetti F.S., 2016. Frequency and intensity of palaeofloods at the interface of Atlantic and Mediterranean climate domains, Climate of the Past 12, 299-316, 2016

Wirth, S.B., 2013. The Holocene flood history of the Central Alps reconstructed from lacustrine sediments : Frequency, intensity and controlling climate factors. PhD Thesis

Wirth, S.B., Glur, L., Gilli, A., Anselmetti, F.S., 2013. Holocene flood frequency across the Central Alps - solar forcing and evidence for variations in North Atlantic atmospheric circulation. Quat. Sci. Rev. 80, 112-128. 
doi:10.1016/j.quascirev.2013.09.002

Zanchetta, G., Van Welden, A., Baneschi, I., Drysdale, R., Sadori, L., Roberts, N., Giardini, M., Beck, C., Pascucci, V., Sulpizio, R., 2012. Multiproxy record for the last 4500 years from Lake Shkodra (Albania/Montenegro). J. Quat. Sci. 27, 780-789. doi:10.1002/jqs.2563

Zhang, X., Reed, J., Wagner, B., Francke, A., Levkov, Z., 2014. Lateglacial and Holocene climate and environmental change in the northeastern Mediterranean region: Diatom evidence from Lake Dojran (Republic of Macedonia/Greece). Quat. Sci. Rev. 103, 51-66. doi:10.1016/j.quascirev.2014.09.004

\section{Figure captions:}

Fig. 1 A. Southern- and eastern-central Europe showing the location of 1) Lake Ighiel (study site) and the other lacustrine records used in comparison: sites from the Alps; 2) Lake Mondsee (Swierczynski et al., 2013); 3) Lake Ammersee (Czymzik et al., 2013); from the Balkans (north-east Mediterranean): 4) Lake Shkodra (Zanchetta et al., 2012); 5) Lake Dojran; 6) Lake Prespa; 7) Lake Ohrid (Lacey et al., 2014); 8) Lake Butrint (Morellon et al., 2015); B. Lake Ighiel geological map. C. Lake Ighiel hypsometric map.

Fig. 2 Mean annual temperature (1961 - 2010) and mean annual precipitation (1923 - 2010), Cluj-Napoca meteorological station (70 km from L. Ighiel).

Fig. 3 Location of coring points: long sedimentological records IGH-1 (used in this study) and IGH-2, and short, gravitational core (SC-4) on a Landsat image (2011, Digital Globe).

Fig. 4 Chronological model for Lake Ighiel's sedimentary record constructed with the Bayesian age modelling package Bacon (Blaauw and Christen, 2013). The top panel shows the iteration history (left), the distribution of the accumulation rate (middle) and the memory (right). The calibrated ages for each sample and subsequent uncertainties are shown in blue. The 95\% confidence interval is represented by dotted, grey eontinuets-lines. The red line represents the model based on weighted mean age at each depth and is used for plotting our proxies. The bottom panel shows the lithological units and the sediment accumulation rate (SAR, $\mathrm{mm} / \mathrm{yr})$.

Fig. 5 Lithological profile plotted against age-depth and subsequent composite depth for IGH-1 with delimited lithological units (see the legend on the bottom panel and Table 2 for more detail) and the depositional model (on the right panel) with main components. 
Fig. 6 Selected geochemical and magnetic proxies, organic/mineral content and lithological description (see lithological legend in Fig.5) for the IGH-1 composite profile. The thick lines for titanium (Ti), silica (Si), potassium (K) and 782 manganese/iron ratio $(\mathrm{Mn} / \mathrm{Fe})$ represent 50-point moving average.

783 Fig. 7 PCA bi-plot for selected sedimentological, geochemical and magnetic proxies plotted on first two components 784 (Component 1 and Component 2) with circles and points coloured according to each lithological unit.

785 Fig. 8 Bi-plot for silica $(\mathrm{Si})$ and potassium $(\mathrm{K})$, iron $(\mathrm{Fe})$ and titanium $(\mathrm{Ti})$ elements for the entire interval. For all the 786 elements intensities are expressed as counts per second (cps).

787 Fig. 9 Bi-plot for calcium (Ca) and titanium (Ti) elements (expressed as counts per second-cps) and carbonate and organic 788 matter content (expressed as percentage - \%) for the periods -62-1250 cal yr BP (lithological unit IV), 1250-2500 cal yr BP 789 (lithological unit III) and 2500-6030 cal yr BP (lithological unit II, I).

790 Fig. 10 Bi-plot for SIRM and $\chi \mathrm{lf}(\mathrm{r}=0,8)$ (right panel) and between ARM/SIRM and $\chi$ lf with the identification of single791 stable domain-SD and pseudo-domain-PSD (right panel). The points were coloured according to each lithological unit.

792 Fig. 11 Main geochemical signal for the Lake Ighiel record in comparison with other regional and extra-regional 793 palaeohydrological and palaeoclimatic reconstructions. Lake Ighiel detrital events are indicated by grey-shaded bands. From bottom to top: principal archaeological periods (Copper Age, Bronze, Iron Epochs and Migration Period) and recent climatic stages (MCA - Medieval Climatic Anomaly, LIA - Little Ice Age), anthropogenic activities documented in the Apuseni Mountains for the last 6000 years (e.g., Fărcaş et al., 2003; Feurdean et al., 2013a; Tanţău et al., 2011), Lake Ighiel geochemical signal (this study), runoff activity in the Balkan peninsula reconstructed based on the Ti/Ca ratio in Lake Butrint (Morellon et al., 2015) and titanium (Ti) behaviour in Lake Prespa (Wagner et al., 2013), reconstructed flood activity in the Alps, in Lake Mondsee (Swierczynski et al., 2013) and Lake Ammersee (Czymzik et al., 2013), regional in N Alps and S Alps (Wirth et al., 2013,) reconstructed NAO index (Olsen et al., 2012) and solar activity (Steinhilber et al., 2009)

Table captions:

803 Table 1 Material subjected to ${ }^{14} \mathrm{C}$ dating and the resulting ages

804 Table 2 Lithological units for IGH-1 with detailed sedimentological description

805 Table 3 Principal Component Analysis (PCA) with: i) eigenvalues, variance and cumulative variance of the first three 806 component and ii) loadings for all variables plotted on first two main axes 
807 Table 4 Coefficient of variance for selected geochemical elements - Si, K, Ca, Ti, Mn, Fe, Rb, Zr calculated for each 808 lithological unit

809

810

Fig.1.

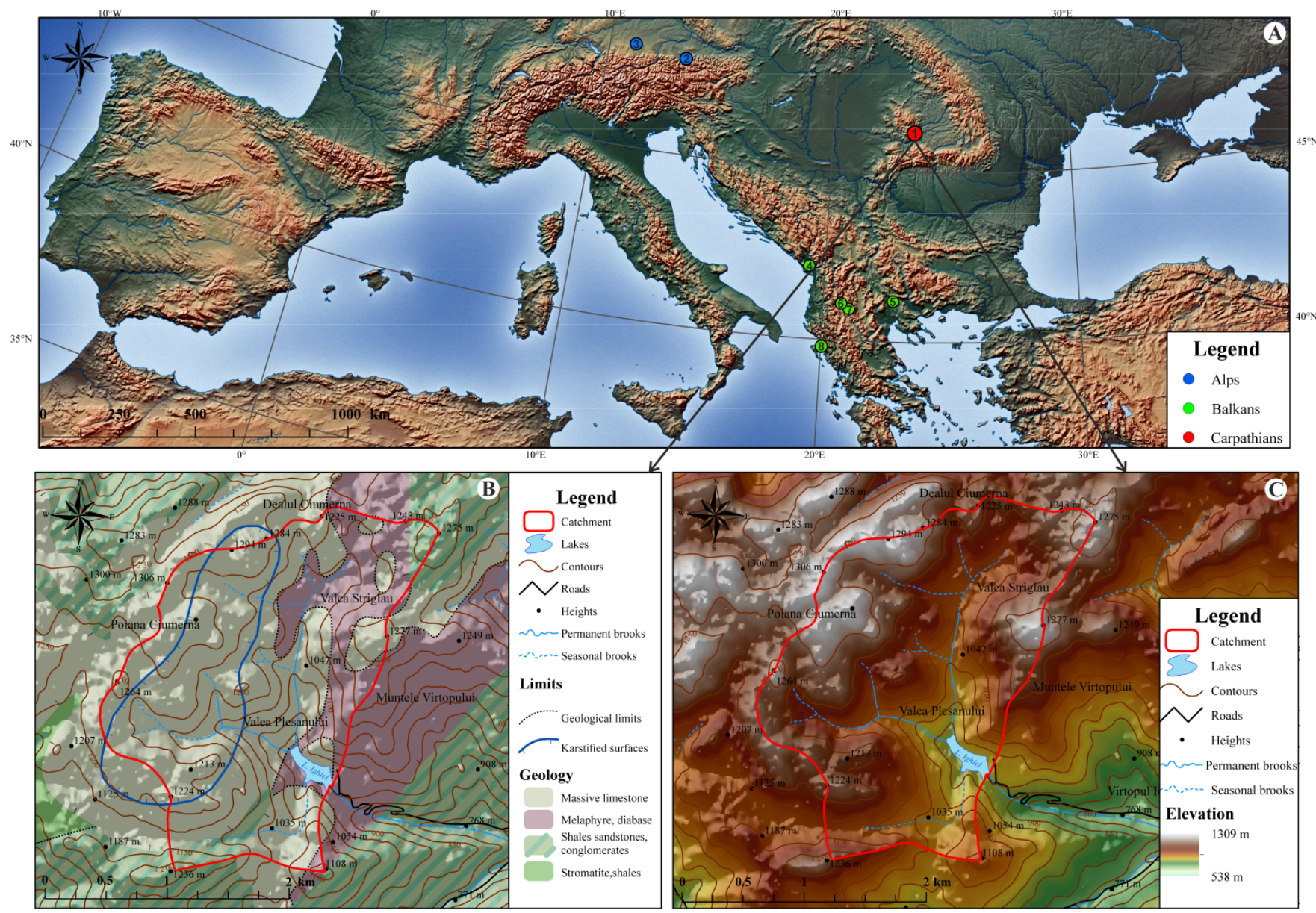

Fig. 2

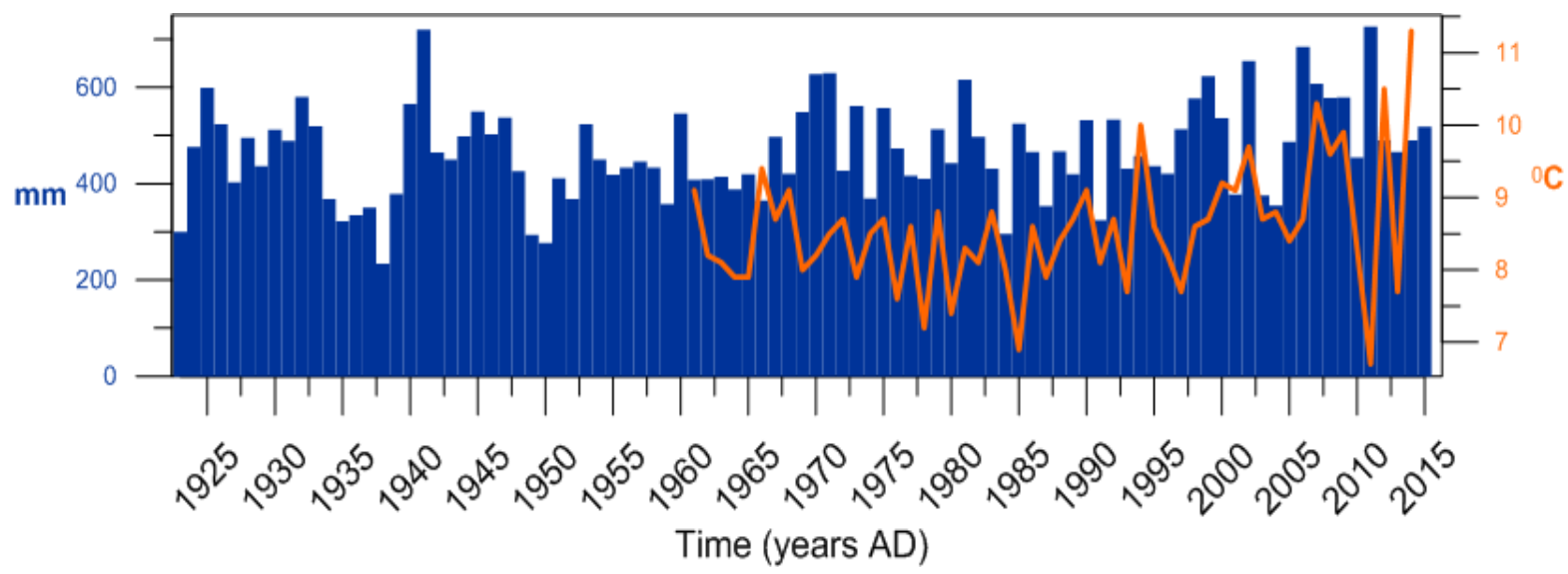


816

817

818

$819 \quad$ Fig. 3

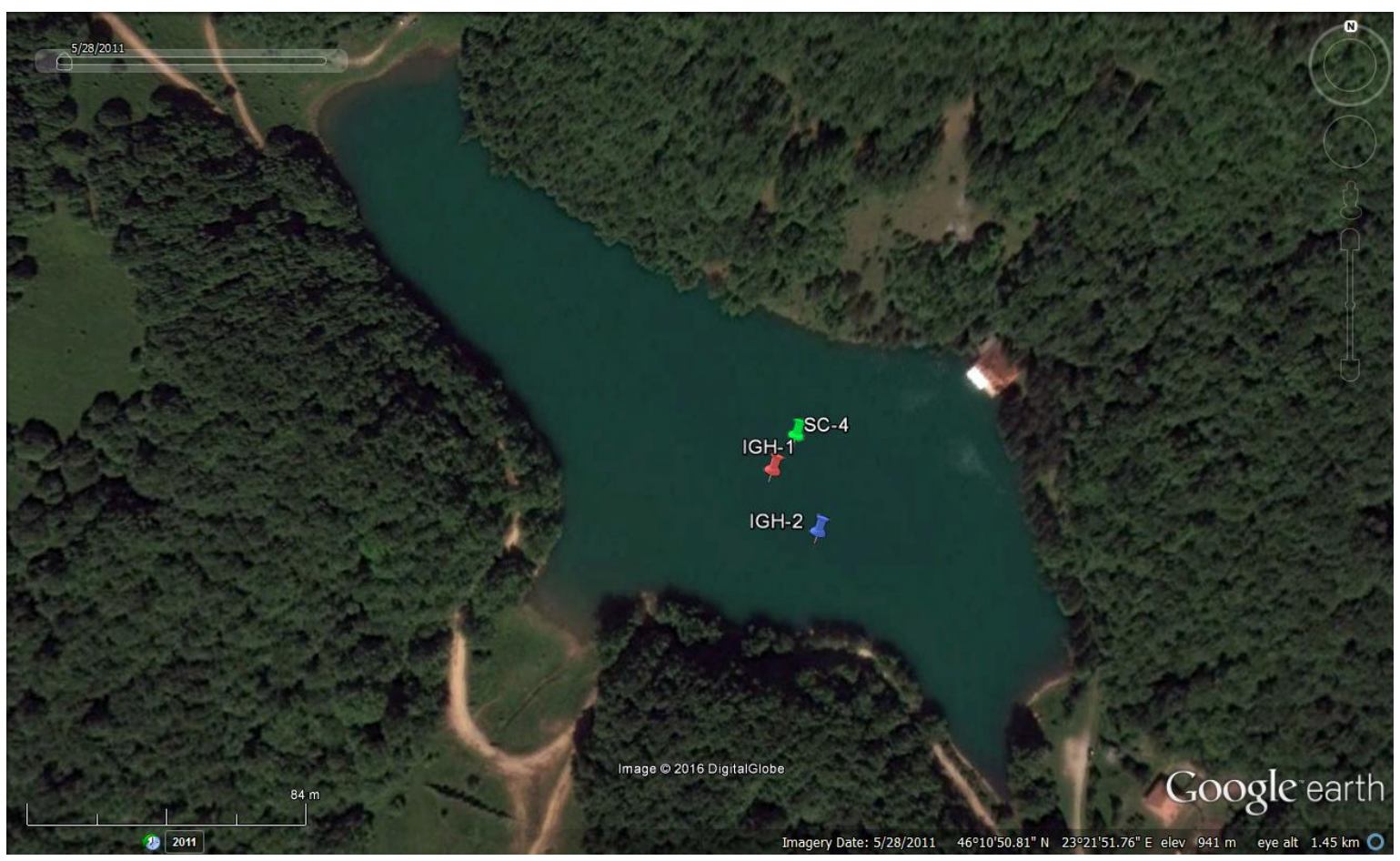

821

$822 \quad$ Fig. 4 


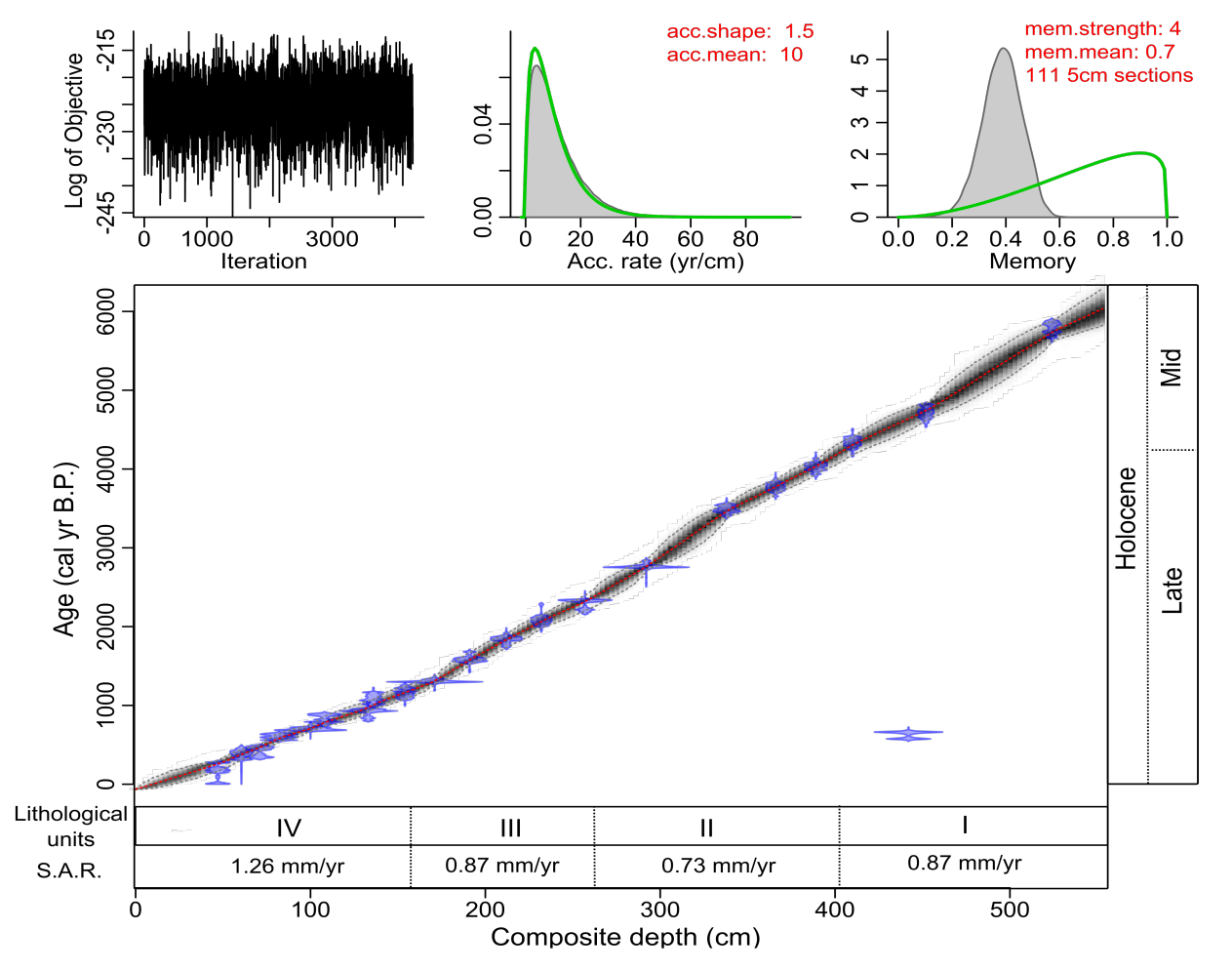

823

824

$825 \quad$ Fig. 5 


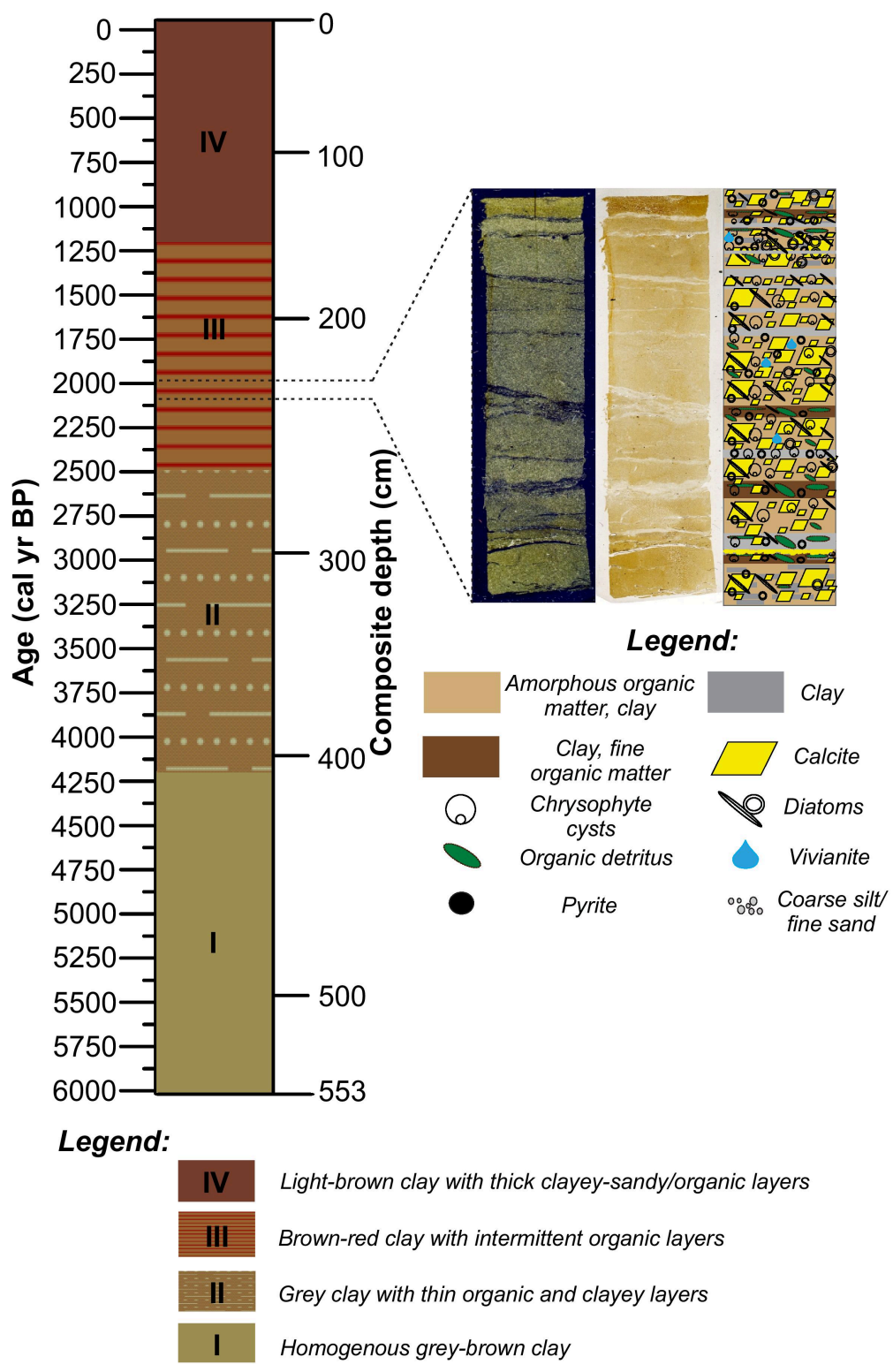




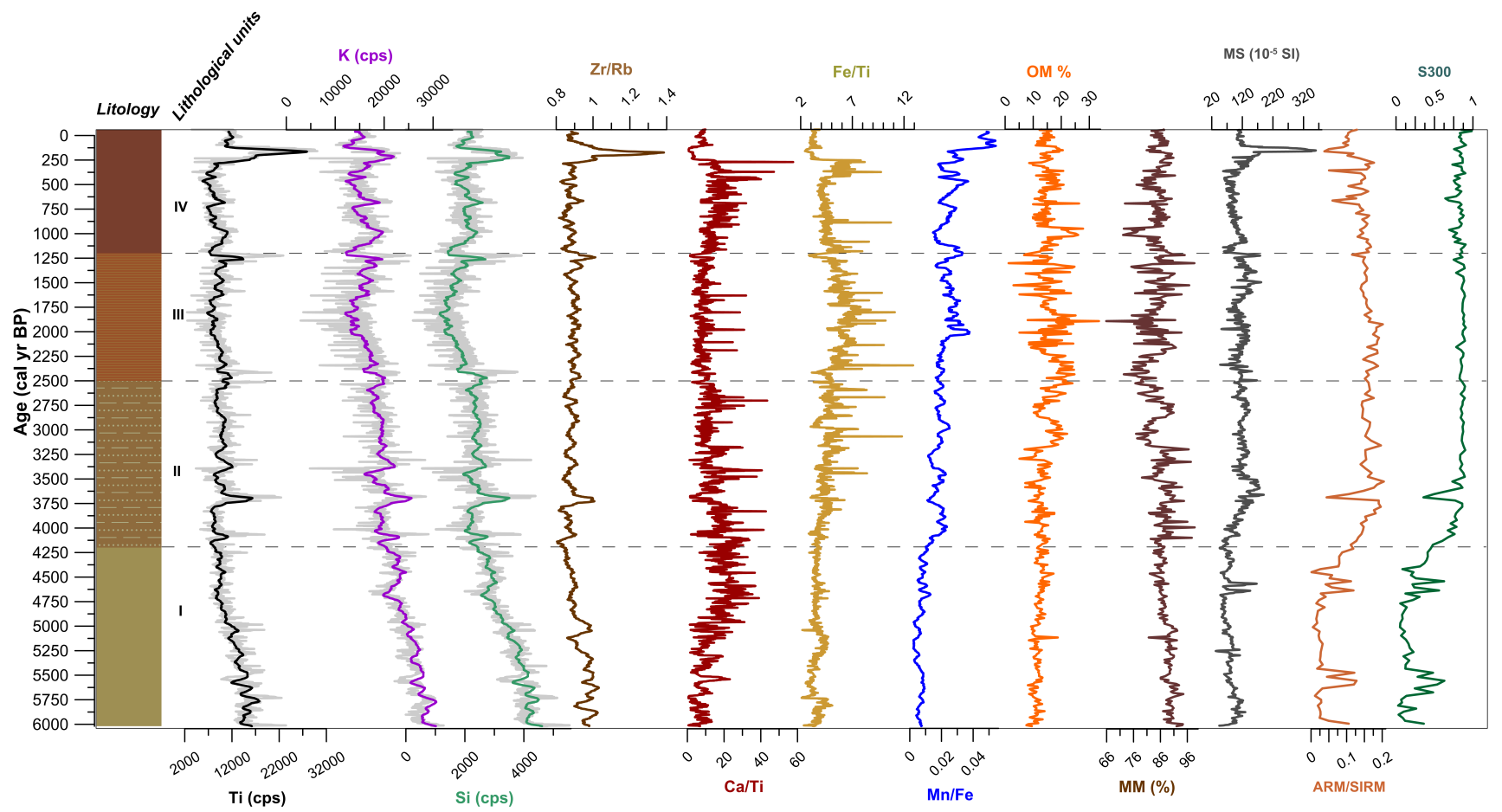

Fig. 7

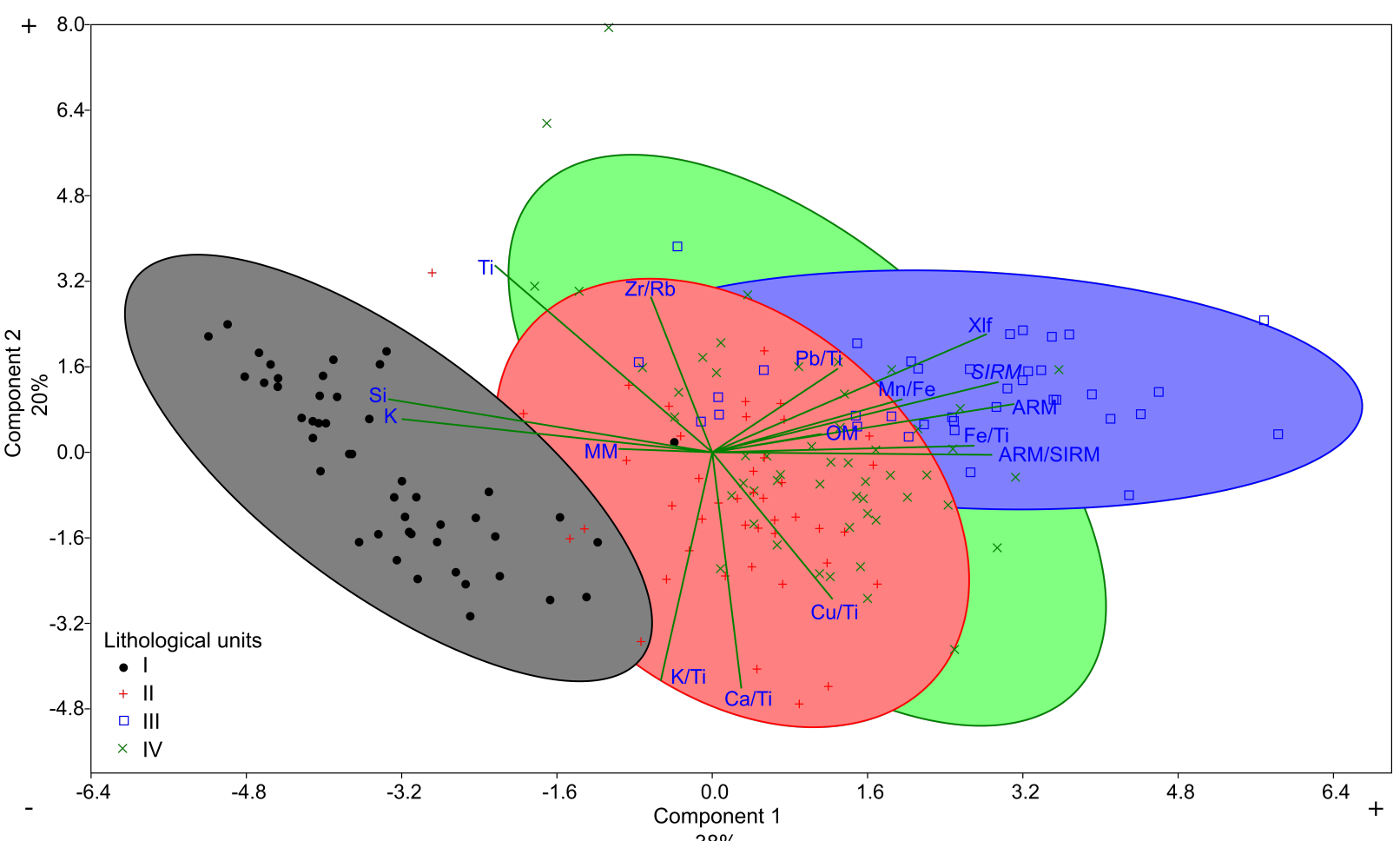


832
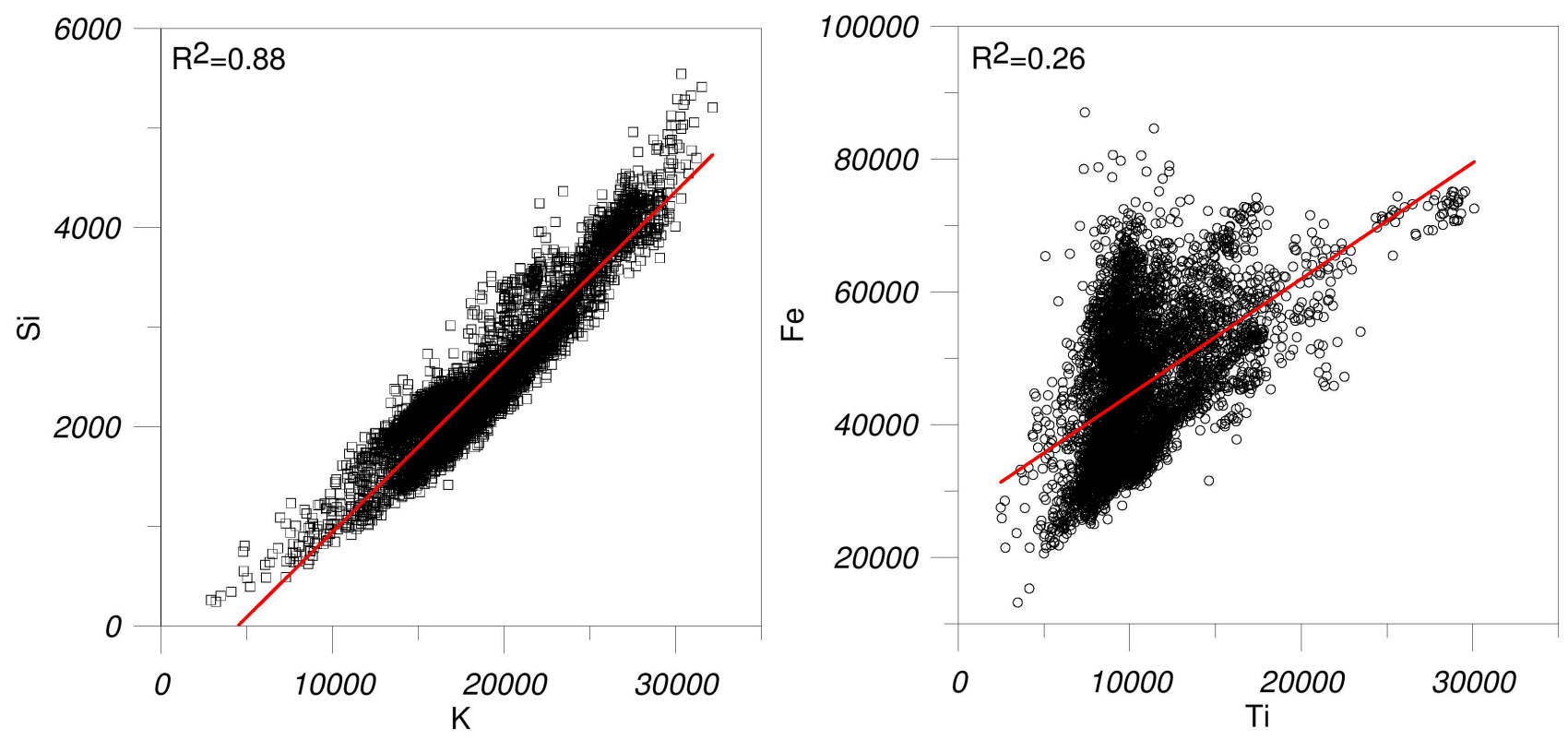

833

Fig. 9
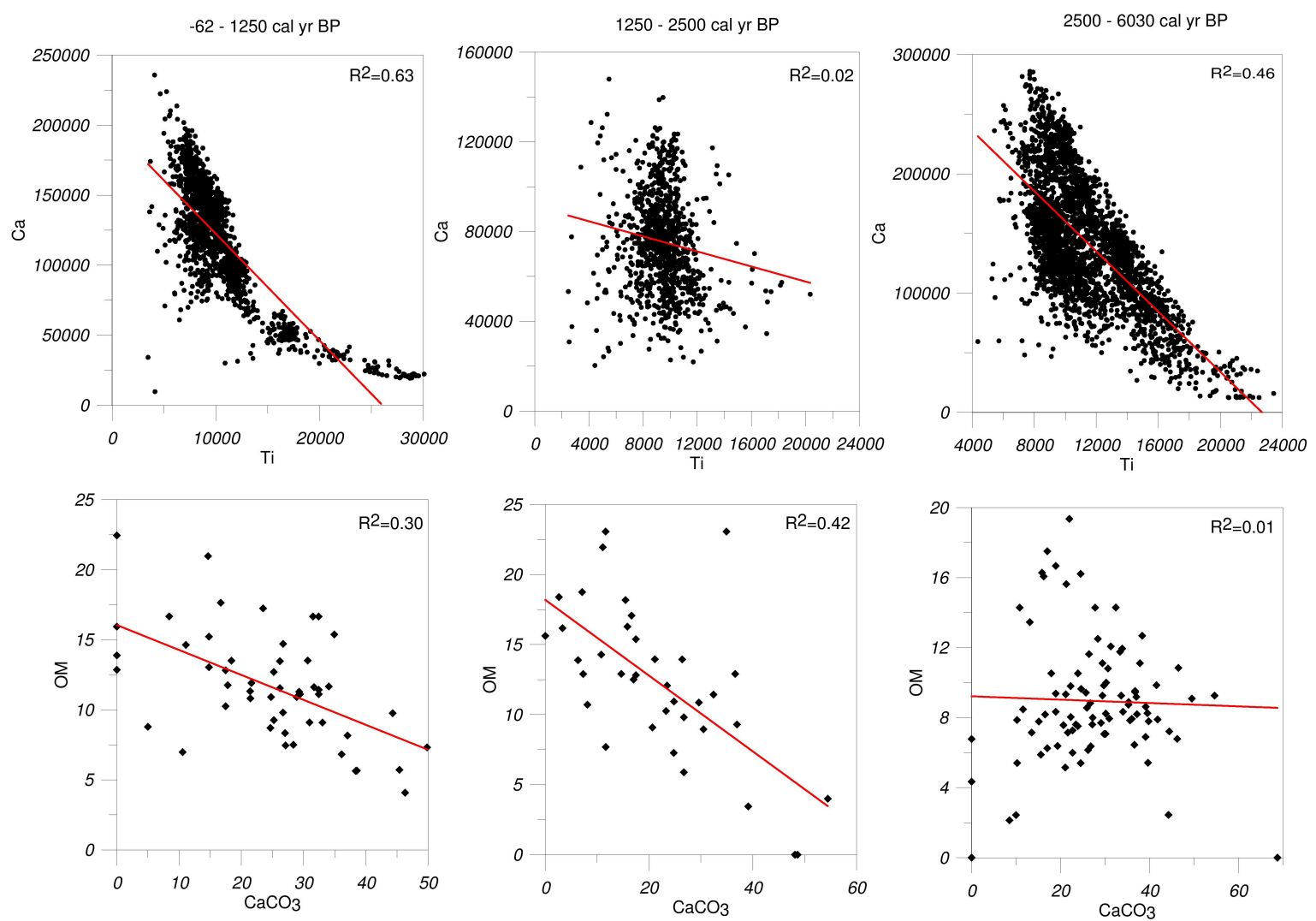

834
835

836 
Fig. 10
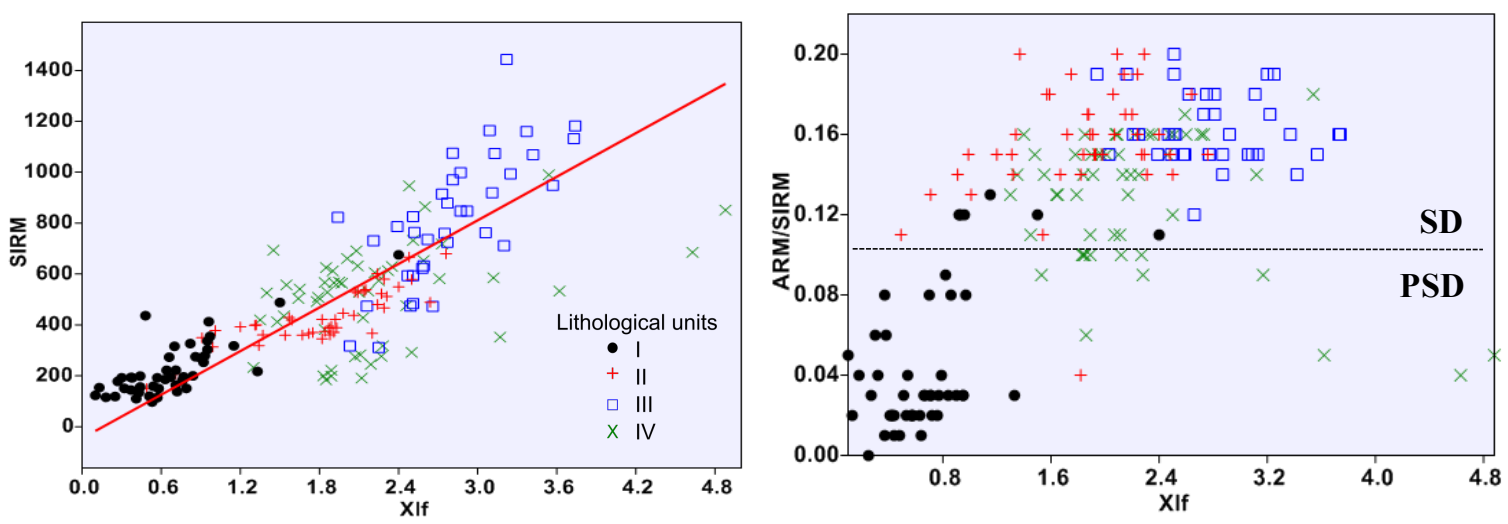

839

Fig. 11

840 


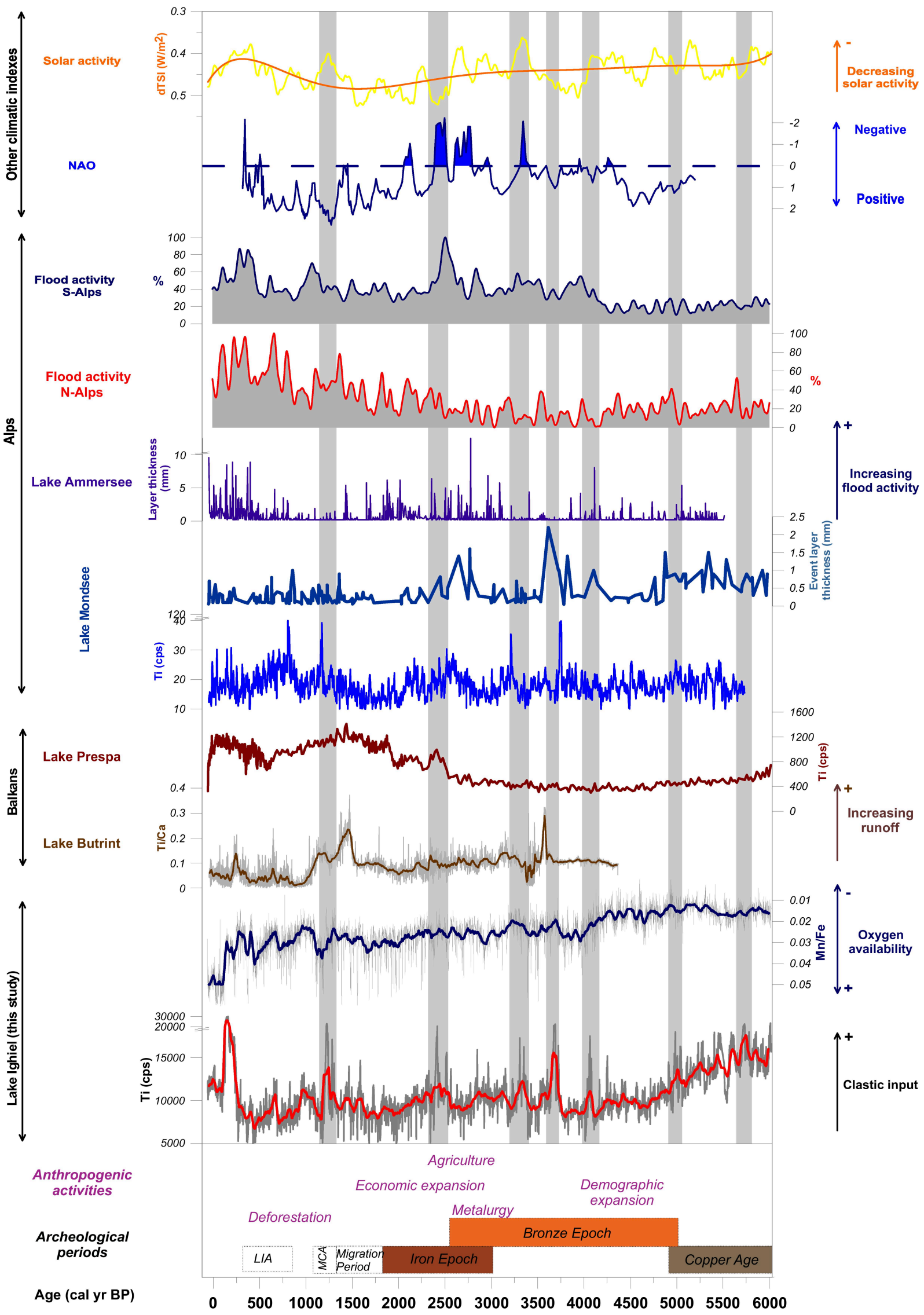


Tab. 1

\begin{tabular}{|c|c|c|c|c|c|c|}
\hline Core & Lab. ID & $\begin{array}{l}\text { Depth } \\
\text { (cm) }\end{array}$ & Dated material & $\begin{array}{c}{ }^{14} \mathrm{C} \text { age } \\
(\mathrm{yr} \mathrm{BP} \pm 1 \sigma)\end{array}$ & $\begin{array}{c}\text { Calendar age } \\
(\text { cal. yr } \mathrm{BP} \pm 2 \sigma)\end{array}$ & Remarks \\
\hline SC-4 & DeA- 6525 & 47 & Fagus leaf & $183 \pm 25$ & $139-293$ & \\
\hline SC-4 & DeA- 6539 & 60.5 & Fagus leaf & $311 \pm 28$ & $302-461$ & \\
\hline IGH-1 & DeA- 6522 & 71 & Fagus leaf & $369 \pm 22$ & $\begin{array}{l}319-391 \\
427-500\end{array}$ & \\
\hline IGH-1 & DeA- 6527 & 82 & Fagus leaf & $610 \pm 21$ & $550-652$ & \\
\hline IGH-1 & DeA- 6528 & 100 & Fagus leaf & $772 \pm 22$ & $674-728$ & \\
\hline IGH-1 & DeA-3704 & 108 & Fagus scale/seed, twigs & $897 \pm 16$ & $744-905$ & \\
\hline IGH-1 & DeA- 6524 & 133 & Fagus leaf & $1008 \pm 27$ & $\begin{array}{l}803-859 \\
904-969\end{array}$ & \\
\hline IGH-1 & DeA- 6526 & 136 & Fagus leaf & $1159 \pm 23$ & $987-1175$ & \\
\hline IGH-1 & DeA- 6529 & 154 & Coniferous bud scale & $1225 \pm 26$ & $1067-1257$ & \\
\hline IGH-1 & DeA-3705 & 171 & Unidentified twig & $1389 \pm 22$ & $1284-1335$ & \\
\hline IGH-1 & DeA- 6530 & 191 & Fagus leaf, bud cuticle, twigs & $1678 \pm 25$ & $1532-1688$ & \\
\hline IGH-1 & DeA- 6531 & 212 & Fagus leaf & $1895 \pm 27$ & $1737-1896$ & \\
\hline IGH-1 & DeA- 6532 & 232 & Fagus leaf, coniferous needle & $2107 \pm 29$ & $1998-2148$ & \\
\hline IGH-1 & DeA-3706 & 257 & Fagus fruit scale & $2291 \pm 27$ & $2184-2352$ & \\
\hline IGH-1 & DeA- 6533 & 292 & Fagus leaf & $2636 \pm 28$ & $2736-2788$ & \\
\hline IGH-1 & DeA- 6535 & 338 & Fagus leaf & $3258 \pm 30$ & $3402-3564$ & \\
\hline IGH-1 & DeA- 6536 & 366 & Fagus leaf & $3500 \pm 31$ & $3653-3858$ & \\
\hline IGH-1 & DeA-3707 & 389 & Fagus seed, twigs & $3685 \pm 26$ & $3927-4139$ & \\
\hline IGH-1 & DeA- 6537 & 410 & Fagus leaf & $3904 \pm 32$ & $4245-4420$ & \\
\hline IGH-1 & DeA- 6538 & 442 & Carpinus? fruit scale & $682 \pm 26$ & $\begin{array}{l}563-591 \\
639-678\end{array}$ & Outlier \\
\hline IGH-1 & DeA-7467 & 452 & Unidentified twigs & $4172 \pm 31$ & $4585-4832$ & \\
\hline IGH-1 & DeA-7468 & 524 & Unidentified twigs & $5024 \pm 34$ & $5661-5892$ & \\
\hline
\end{tabular}

Tab. 2

\begin{tabular}{ccccccc}
\hline $\begin{array}{c}\text { Litho- } \\
\text { units }\end{array}$ & \multicolumn{2}{c}{$\begin{array}{c}\text { Age (cal yr } \\
\text { B.P.) }\end{array}$} & Depth (cm) & Lithology & Description \\
\hline IV & -62 & 1200 & 0 & 159 & Light-brown clay & $\begin{array}{c}\text { Soft light-brown clay with black-brown, organic } \\
\text { and sandy laminations }\end{array}$ \\
III & 1200 & 2500 & 159 & 272 & Brown-red clay & $\begin{array}{c}\text { Brown-red clay with black-brown, organic and } \\
\text { grey, clayey laminations }\end{array}$ \\
II & 2500 & 4200 & 272 & 403 & Brown-grey clay & $\begin{array}{c}\text { Brown-grey clay with faint black-brown, organic } \\
\text { and grey, clayey and sandy laminations } \\
\text { Homogeneous grey-brown sandy clay }\end{array}$ \\
I & 4200 & 6030 & 403 & 553 & Grey-brown sandy clay & .
\end{tabular}

Tab. 3

\begin{tabular}{|c|c|c|c|}
\hline i) $\mathrm{PC}$ & Eigenvalue & $\%$ variance & $\underset{\%}{\text { Cumulative }}$ \\
\hline
\end{tabular}




\begin{tabular}{|c|c|c|}
\hline 6.037 & 37.732 & 37.732 \\
\hline 3.213 & 20.079 & 57.811 \\
\hline 1.658 & 10.360 & 68.171 \\
\hline \multirow[t]{2}{*}{ ii) } & \multicolumn{2}{|c|}{ Component } \\
\hline & PC 1 & PC 2 \\
\hline ARM & 0.351 & 0.102 \\
\hline $\mathbf{S i}$ & -0.377 & 0.112 \\
\hline $\mathbf{K}$ & -0.361 & 0.070 \\
\hline $\mathbf{T i}$ & -0.253 & 0.395 \\
\hline $\mathbf{M n} / \mathbf{F e}$ & 0.221 & 0.112 \\
\hline $\mathbf{Z r} / \mathbf{R b}$ & -0.072 & 0.329 \\
\hline $\mathrm{K} / \mathrm{Ti}$ & -0.060 & -0.482 \\
\hline $\mathrm{Pb} / \mathrm{Ti}$ & 0.146 & 0.177 \\
\hline $\mathbf{C u} / \mathbf{T i}$ & 0.140 & -0.310 \\
\hline OM & 0.127 & 0.039 \\
\hline MM & -0.109 & 0.007 \\
\hline$\chi \mathbf{l f}$ & 0.319 & 0.250 \\
\hline SIRM & 0.333 & 0.149 \\
\hline ARM/SIRM & 0.326 & -0.005 \\
\hline $\mathrm{Ca} / \mathrm{Ti}$ & 0.034 & -0.499 \\
\hline $\mathbf{F e} / \mathbf{T i}$ & 0.305 & 0.014 \\
\hline
\end{tabular}

847

848 Tab. 4

\begin{tabular}{|c|c|c|c|c|c|c|c|c|c|c|}
\hline $\begin{array}{c}\text { Lihological } \\
\text { unit }\end{array}$ & Si & $\mathbf{K}$ & $\mathbf{C a}$ & $\mathbf{T i}$ & Mn & $\mathrm{Fe}$ & $\mathbf{R b}$ & $\mathbf{Z r}$ & \multicolumn{2}{|c|}{ Coefficient of variance $\%$} \\
\hline IV & 0.21 & 0.16 & 0.33 & 0.39 & 0.30 & 0.24 & 0.19 & 0.36 & 27.18 & High \\
\hline III & 0.28 & 0.18 & 0.30 & 0.24 & 0.19 & 0.15 & 0.19 & 0.28 & 22.56 & Weak \\
\hline II & 0.16 & 0.13 & 0.30 & 0.22 & 0.29 & 0.23 & 0.18 & 0.30 & 22.63 & Weak \\
\hline I & 0.17 & 0.11 & 0.41 & 0.23 & 0.34 & 0.24 & 0.18 & 0.28 & 24.42 & Moderate \\
\hline
\end{tabular}

849 